\title{
The animal names in the Book of Leviticus of the Gözleve Bible (1841). Part II: Bird species
}

\author{
MURAT IŞIK
}

Department of Altaic Studies, University of Szeged, H-6722 Szeged, Egyetem u. 2. Hungary

Faculty of Philology, Jagiellonian University, ul. Gołębia 24, 31-007 Kraków

Received: August 25, $2020 \bullet$ Accepted: November 12, 2020

(c) 2021 The Author

\section{Abstract}

This paper is a continuation of a previous study that presented the names of mammal, insect, and reptile species appearing in the Book of Leviticus of the so-called Gözleve Bible. The present study aims to survey the rest of the animal names in the corpus, representing bird species. The translation shows a mixed vocabulary and therefore the distribution of the Kipchak, Oghuzic, and non-Turkic elements will be compared with their equivalents in some of the other books of the Gözleve Bible, a recently published critical edition of another Crimean Karaim Bible, and some Ottoman Turkish Bible translations.

\section{KEYWORDS}

bird names, Karaim Bible translations, Ottoman Turkish Bible translations, Gözleve Bible, the Book of Leviticus, Crimean Karaim, Oghuzic characteristics, Kipchak characteristics

*Corresponding author.E-mail: murat_i@anadolu.edu.tr, murat.isik@uj.edu.pl 


\section{PRELIMINARY REMARKS}

This article is a continuation of Işı (2020), in which some animal names (denoting mammal, insect, and reptile species) that appear in the Book of Leviticus ${ }^{1}$ (hereinafter referred to as Lev) of the Gözleve Bible (hereinafter referred to as Göz. 1841) were presented and compared to the Lev of the recently published critical edition of another Crimean Karaim Bible translation (hereinafter referred to as $\mathrm{CrKB}$ ). In the Lev of the Göz. 1841, there are altogether 58 different animal names referring to mammals (20), insects (4), reptiles (5), birds (23), and the main group names of animals (6). In my previous study, 29 of 58 animal names were investigated. In this paper, 23 words that denote the bird species will be presented and compared to the Lev of CrKB.

As I mentioned in my previous study (Işı1k 2020: 145-146), the so-called Göz. 1841 is a complete translation of the Tanakh (without the Chronicles) into Karaim, which was printed in four volumes in Gözleve (present-day Eupatoria) in 1841 (Jankowski 2018: 51). The language of this edition was modernised by its editors to adapt it to Turkish and therefore includes mixed characteristics (CrKB I: XX). Recently, the language of this edition was discussed by certain scholars (e.g. Shapira 2003, 2013, Németh 2015, 2016, Olach 2016, Işık 2018). However, it is difficult to reach an unambiguous conclusion based on specific parts of the Göz. 1841, since the language of the whole edition is not homogenous. Nonetheless, it is possible to say that the Lev of the Göz. 1841 presents Crimean Kipchak Karaim and Crimean Turkish Karaim features ${ }^{2}$, and therefore shows mixed Kipchak and Oghuzic characteristics ${ }^{3}$. On the other hand, the principal manuscript for the CrKB translation comprises volume I and volume IV of BSMS 288, which is preserved in the Cambridge University Library in four volumes. Similar to the Göz. 1841, this manuscript contains the complete Tanakh without the Chronicles. Note that the Göz. 1841 (in the CrKB edition) was also used for some unavailable or unclear fragments of BSMS 288 since scholars opined that the general linguistic form of these translations is similar (CrKB I: XX). At the same time, the CrKB includes some other manuscripts, e.g. H 170 (Gaster) and B 282, as well as some short fragments, e.g. JSul.III.02, Baxč. 116, Evr I 143, Evr I 144, Or. Ms. 1694. For this article, the related examples of the Lev were taken from CrKB I: 165-217.

The present study will use similar sources to those used in the previous paper to describe the data and demonstrate the existing Oghuzic-Kipchak contrasts ${ }^{5}$, although here, two Ottoman Turkish Bible translations ${ }^{6}$ will also be used to present the significant similarities that occur between Chapter 11 of the Lev translations of the Ottoman Bible translations and the Göz. 1841. ${ }^{7}$

\footnotetext{
${ }^{1}$ In this paper, some relevant examples from the other Books of the Göz. 1841 are also presented. However, this comparison comprises only the translation of the Pentateuch (Torah) of the Göz. 1841, as was the case with the previous paper.

${ }_{2}^{2}$ For a description regarding the features of these dialects, see Jankowski 2015: 202-205 and for the debates on the existence of Crimean Karaim, see Jankowski 2015: 202-204, Németh 2016: 209-211, Shapira 2003: 661-662.

3 As for the distribution of these characteristics, see Işık 2018: 74.

4 The further details on the manuscripts/short fragments that were used for the Lev of the CrKB are present in the Appendix. For descriptions of the aforementioned other manuscripts and short fragments, see CrKB I: XVI-XX.

${ }^{5}$ It is worth repeating that the examples of English and Russian Bible translations were collected from software called 'Bible Works 9'. In addition, a website (www.biblehub.com) was also very helpful in terms of viewing 29 different English Bible translations for the relevant parts of the Hebrew Bible.

6 The transcription of the forms in the Ottoman Turkish Bibles was performed by the author.

7 This comparison was not present in the previous study. For the new results from the previous data, see 3.2.
} 
One of these Ottoman Turkish Bible translations was made by Ali Bey (also known as Ali Ufkî and Wojciech Bobowski) between 1662-1664 in Istanbul. The so-called secretarial/fair copy was printed in Leiden in 1665. Although this translation was not the first translation of the Bible into Turkish, it is considered the first translation that contains the entire Bible including the Old Testament (together with Apocrypha) and the New Testament (Pawlina 2006: 34). The draft and the secretarial copies are preserved in Leiden ${ }^{8}$, while another fair copy together with some corrections made by Şahin ibn Kandi is preserved in Amsterdam ${ }^{9}$. Ali Bey's translation (hereinafter referred to as Ali Bey 1665) has been revised many times through the years (see Privratsky 2014: 22-50). One of the first attempts was made by Baron H. F. von Diez, who was assigned to lead a project by the British Bible Society in 1814. After his death in 1817, Jean Daniel Kieffer joined the project. In 1819, the translation of the New Testament was published. Later, Kieffer included the first four books of Ali Bey's Pentateuch, which had been edited by Baron H. F. von Diez, together with a revised version of the 1819 New Testament translation in his 1827 Bible edition ${ }^{10}$ (hereinafter referred to as Kieffer 1827) in two volumes ${ }^{11}$ (Privratsky 2014: 44).

\section{BIRD SPECIES}

In the Tanakh, the Lev specifically describes which animals are clean or unclean to eat and/or sacrifice $^{12}$. In the Lev of the Göz. 1841, there are altogether 23 different bird names. However, with the exception of kumru 'turtle-dove', and kögürčin/gögürčün 'pigeon', all of the words occur only once throughout the book. Besides this, except for kumru and tor 'turtle-dove' and kartal and karakuš 'eagle', all the examples are the only words for the relevant bird species. On the other hand, the Lev of the CrKB does not show any synonyms for bird names, and therefore it presents only 21 different words. Another important point is that, except for aya 'hawk' (see 2.7.), which occurs in the Lev of the CrKB, the bird names that are identical/similar to the Biblical Hebrew forms ${ }^{13}$ in the Lev of these two Karaim Bible translations were not attested in the most common Karaim

\footnotetext{
${ }^{8}$ Ali Bey's rough draft (Cod. Or. 390a-d), his proof sheet which was printed in 1662 (Cod. Or. 390e), the secretarial 'fair copy' (Cod. Or. 1101a-f), and the incomplete secretarial fair copy (Cod. Or. 1117a) are preserved in the Leiden University Library as a part of the Warner Collection (see Privratsky 2014: 19). A website (https:// www.osmanlicakelam.net) also provides digital photocopies of the original manuscripts together with their transcriptions.

9 A fair copy (MS J 69c) and another fair copy (MS VI H 2) lacking the Pentateuch, Apocrypha, and New Testament are preserved in the library of Amsterdam University (see Privratsky 2014: 19).

${ }_{10}$ The exact titles of the volumes are Kitab ül-ahd el-atik (the Old Testament) and Kitab ül-ahd el-cedid elmensub ila Rabbina İsa el-Mesih (the Book of the New Testament of our Lord Jesus Christ).

11 This edition can be accessed at Bayerische Staatsbibliothek and Münchener Digitalisierungszentrum. In addition, the web site (https://www.osmanlicakelam.net) also presents this edition together with its transcription. 12 Aside from kögürčin/kögürčün/gügürčin/gögürčün 'pigeon' and kumru; tor 'turtle-dove', all the bird species that were listed in Lev are unclean to eat.

13 The transcription of the Lev of the Göz. 1841 was performed by the author based on a system that was presented in CrKB I: XXIV-XXV.
} 
dictionaries. Thus, such unlisted Biblical Hebrew forms will be treated as untranslated words ${ }^{14}$, as was the case in the previous study. Below, all the words discussed will be listed according to their occurrence in the Lev.

\section{1. kögürčin/kögürčün/gügürčin/gögürčün}

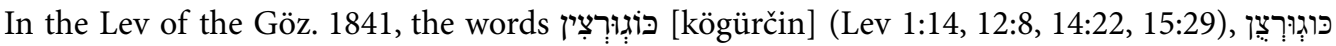

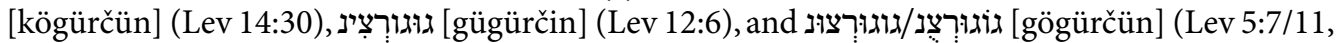

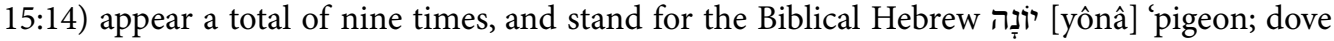
(columba)' (CEDHL: 256, LVTL: 374). According to Clauson (EDPT: 671), the word kögürčgün means 'pigeon; dove' and probably goes back to the word kök 'sky' with the meaning 'grey bird', whereas Róna-Tas (WOT I: 546-547) remarks that the word kögürčgün is probably a denominal form from kögär-/kögür- 'to turn blue/grey' (cf. ESTJa 3: 58-59) with the suffix -čUk (cf. OTWP

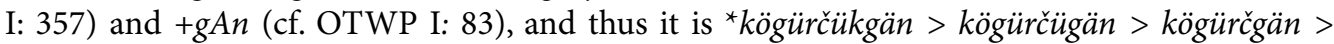
kögürčän > kögärčän. However, the word kögürčgün has been attested since the $7^{\text {th }}$ century with different phonological changes in many Turkic sources, e.g. DLT III: 419 kökürçkün, CC: 157 kügürčin 'pigeon', and Turkic languages. In the Lev of the Göz 1841, these slightly contrasting forms also show one of the main phonological differences between the Oghuzic and Kipchak languages, as the voicing of the initial plosive $k->g$ - occurs in the Oghuzic languages and also in Crimean Tatar for some words, e.g. Tur. ${ }^{15}$ güvercin, Az. göyärčin, Trk. gögerčin, CrTat. gögerğin 'pigeon', whereas the unvoiced initial plosive $k$ - is preserved in the Kipchak languages (TTL: 100), e.g. Kaz. kögeršin, Kir. kögüčkön, Tat. kügärčän, 'pigeon' (DTMK: 113, ESTJa 3: 57-59, EDPT: 713, L: 174, KEWTS: 165). In the Lev of the CrKB, the word was translated as kögürčün throughout the Book. It is worth noting that only the examples that show the Kipchak phonological characteristic (kögürčin, kögürčün) were listed in the Karaim dictionaries (CKED: 216, KRPS: 336). In conclusion, both of the Karaim translations present the Turkic words for this bird species. Nevertheless, the Lev of the Göz. 1841 demonstrates both Kipchak-Oghuzic counterparts ${ }^{16}$ together, unlike the Lev of the CrKB.

\footnotetext{
14 Some of the animal names in the Hebrew Bible are still disputed, which therefore has caused certain problems in the Bible translations. First of all, some of the Biblical Hebrew words are not present in modern Hebrew and their definitions have remained uncertain, which might be related to the folk taxonomy of the ancient Hebrews (for further details, see Cansdale 1970, Ferguson 1974). Moreover, certain words are also hapax legomena, which causes difficulties in analysing the forms. Thus, some different preferences regarding the uncertain identification of animal names have also been followed in different Bible translations (see, e.g. some possible influence regarding names of certain animals between the Slavonic-Russian Pentateuch from the $15^{\text {th }}$ century and the Turkic [Western Kipchak] Targum of the Torah was discussed in Griščenko 2017a, 2017b).

15 It should be noted that the word gögürčin had been preserved in Ottoman Turkish (RTD I: 577), while a similar form had also been used in both Ottoman Bible translations, e.g. Ali Bey 1665, Lev 1:14 كُوكُرْجِنْ [gögerjin], Kieffer 1827, Lev 1:14 كُوكرجِين [gögerjin]. Nevertheless, these Ottoman Turkish forms do not survive in modern Turkish. 16 The Oghuzic characteristic mentioned predominates slightly over the Kipchak form of this bird name (56\%$44 \%)$.
} 


\section{2. ḳumru}

The Lev of the Göz. 1841 contains the word קוּמְרוּ [kumru] 'turtle-dove' (KRPS: 374) eight times (Lev 1:14, 5:6/7, 12:6/8, 14:22, 15:14/29) ${ }^{17}$ to indicate the Biblical Hebrew [tôr] 'turtle-dove (streptopelia turtur); other species of columba' (CEDHL: 695, LVTL: 1023). The word kumru ${ }^{18}$ was also attested in Ottoman Turkish as kumri $^{19}$, which is of Arabic origin (NS: 485). In the modern Turkic languages, this loanword is preserved in the Oghuz branch and Crimean Tatar, e.g. Tur. kumru, Az. qumru, Trk. гумры [gumrï] (TDTLM: 45, KEWTS: 238), CrTat. къумру [kumru] (KRUS: 301) 'turtle-dove', whereas the Kipchak languages have different words for this bird species, e.g. Kaz. орман кептер [orman kepter], Kir. бактек [baktek], Tat. урман күгерчене [urman kügärčene] (TDTLM: 45). In the Lev of the CrKB, the word was not translated into Karaim and therefore it occurs in the Biblical Hebrew form tor. Consequently, the Lev of the Göz. 1841 illustrates a loanword that was mainly used in the Oghuzic area, whereas the Lev of the CrKB displays an untranslated Biblical Hebrew word.

\section{3. ḳartal/ḳara ḳuš}

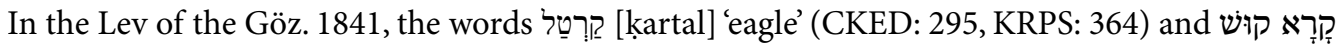
[ḳara ḳuš] 'eagle' (CKED: 291, KRPS: 363), which denote the Biblical Hebrew נְֶֶׁ [nešer] ${ }^{20}$ 'eagle; vulture' (CEDHL: 430, LVTL: 640-641), occur next to each other on one occasion $(11: 13)^{21}$. Although the word kartal does not exist in the modern Kipchak languages (DTMK: 121-122), it is possible to find the word kara kuš 'eagle’ beginning from the early texts, e.g. IrqB: $8 k(a) r a k u s ̧$, KB: 398 ḳarakuš, DLT I: 331 karakuş, CC: 193 qara-quš 'eagle’ to the modern Turkic languages in similar forms e.g. Tur. karakuş 'imperial eagle’ (aquila heliaca), Az. $\dot{g} a r a \dot{g} u s ̌$, 'eagle', Trk. garag்uš 'imperial eagle' (aquila heliaca), Kaz. qara qus 'Egyptian vulture' (neophron perenopterus), Tat. qaraqoš 'eagle', CrTat. qara quš 'eagle; the bearded vulture (gypaetus barbatus)' (DTMK: 122, ESTJa 6: 183, EDPT: 670). In the Lev of the CrKB, the word was also translated as karakuš. According to Clauson (EDPT: 648-649), the word kartal probably means 'spotted, striped'22 and 'eagle, vulture' (cf. KEWTS: 207). Therefore, he claims that the word initially had denoted a 'spotted, striped bird', which later has been attested in Ottoman Turkish as kartal 'Arabian vulture' (vultur monachus) and in modern Oghuz languages in identical/similar forms, e.g. Tur., Az. kartal, Trk. gartal 'eagle' (ESTJa 5: 316-317, L: 169). Therefore, although both of the Karaim Bible translations present a Turkic word in common use for this bird species, the Lev of the Göz. 1841 also presents an Oghuzic counterpart. In fact, this Oghuzic form has also been attested in the Ottoman Bible

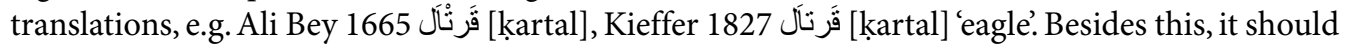

17 It must be noted that of the eight occurrences, the word appears as [kum] in Lev 5:11 due to a scribal error.

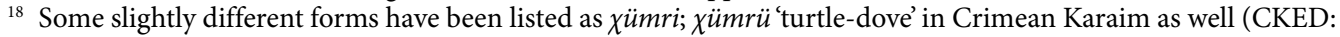
188, KRPS: 605).

19 The same form has also been attested in Ottoman Bible translations, e.g. Ali Bey 1665, Lev 1:14, قُمزْي [kumri], Kieffer 1827 Lev 1:14, قُمرِي [kumri]. According to Nişanyan, one of the earliest sources showing the word kumri in Ottoman Turkish was Süheyl ü Nevbahar, which was a translation by Mesud b. Ahmed in 1354 (see references).

${ }^{20}$ It is worth noting that the word nešer has also been listed in Crimean Karaim, meaning 'eagle' (CKED: 252, KRPS: 423).

${ }^{21}$ The word kara $k u s ̌$ appears in parenthesis as a synonym next to the word kartal.

22 This meaning was also attested in DLT I: 483 as kartal koy'the striped sheep'. 
be pointed out that the word נֶשֶׁ [nešer] appeared altogether five times in the entire Torah (Pentateuch). However, apart from the Lev, the same Biblical form was exclusively denoted as karakuš

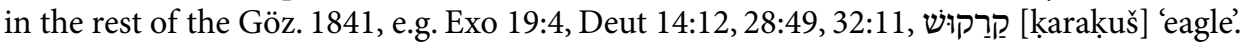

\section{4. ironï}

The word אירוֹני [ironi] ${ }^{23}$ appears once in Lev 11:13 of the Göz. 1841 as another unclean bird of prey, standing for the Biblical Hebrew פֶר אירס [peres], which has been described as 'bearded vulture (gypaetus barbatus); lämmergeier (lit. lamb's vulture)', whereas its literal meaning might also be 'ossifrage (bone-breaking)' (CEDHL: 530, LVTL: 779).

In Turkic languages, there are different words that stand for gypaetus barbatus, e.g. Tur. sakall akbaba; kuzu kartali; nuri kuşu, Az. ġuzugapan; toүlugötürän, Trk. бyprym [bürgüt], Kaz. козыюумай [kozïkumay], Tat. bäränqaraq; бэрэн беркете [bärän berkete], CrTat. къаракъуш [ḳaraḳuš] (DTMK: 235, TDTLM: 72, Turan 1990: 72).

In the Lev of the CrKB, the word occurs as peres, which once again goes back to the Biblical Hebrew form. The exceptional example ironï in the Göz. 1841 does not occur in the Karaim dictionaries, either in the best-known early Turkic sources or Turkic languages. However, in the Ali Bey 1665, the same Biblical word has been translated as آرَوَْن [eron/erun], which appears as إرؤن [iron/irun] in the Kieffer 1827. The word ارون [irûn] is of Persian origin and denotes 'eagle' (CPED: 40). Ergo, the word ironï can be traced back to the Kieffer 1827 translation. As will be demonstrated, some words that were copied from the Ottoman Bible translations into the Lev of the Göz. 1841 have an extra ACC marker as a copy error (see 3.3.). In this case, the ending vowel in the word ironï can be traced back to the Oghuzic ACC marker that was attached to the main word in the Kieffer 1827.

Finally, it should be noted that apart from Lev 11:13, the same Biblical word appears only in Deut 14:12 in the entire Hebrew Bible. However, in Deut 14:12 of the Göz. 1841, the word has remained untranslated as פֶרֶ [peres], unlike the example from Lev 11:13 of the Göz. 1841.

\section{5. degiz ḳartalï}

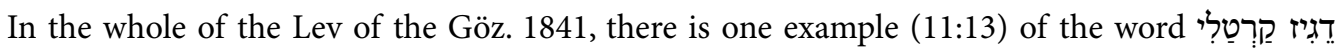

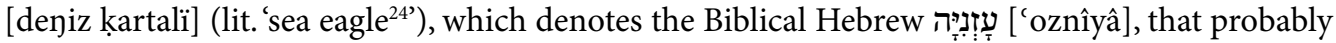
stands for 'black vulture' (aegypius monachus) (CEDHL: 468, LVTL: 695). This compound noun was not listed in the Karaim dictionaries, whereas it was attested in Ottoman Turkish (TS II: $1080)^{25}$, and it is still preserved in Turkish as deniz kartalı (haliaeetus albicilla) (ÖTS 2: 1160). Moreover, the Turkic word was also present in the Ottoman Turkish translations, e.g. Ali Bey 1665

${ }^{23}$ Due to the Hebrew writing system, the vowels $i, \ddot{i}$, and $o$ in the word might also be read with their front/back counterparts.

${ }^{24}$ There exist some English Bible translations that translate this unclear word as 'sea-eagle' (e.g. BST, DBT), similar to the Lev of the Göz. 1841, whereas 'black vulture' (e.g. ESV, NLT), 'buzzard' (e.g. NASB, NKJV), 'osprey' (e.g. KJB, JB2000), and 'Egyptian vulture' (e.g. CSB) can also be attested.

25 According to the dictionary, one of the earliest occurrences of the word in the written sources was from Ahter- $i$ Kebir, which was an Arabic-Ottoman Turkish dictionary written by Mustafa Ahteri in 1545 (see references). 


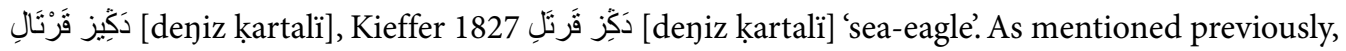
the word kartal seems Oghuzic, while the word deyiz (CKED: 135, KRPS: 184) 'sea' also shows the Oghuzic voicing of the initial $t->d$-, e.g. CrTat. teñiz 'sea' vs Ot. deniz 'id'. (KW: 141-142). Therefore, the Lev of the Göz. 1841 presents an Ottoman Turkish and/or Oghuzic word, whereas the Lev of the CrKB displays the identical Biblical Hebrew word as 'azniya for this bird species. Note that the Biblical form also appeared once in Deut 14:12 of the Hebrew Bible. However, in Deut of the Göz. 1841, the word was not translated into Karaim, and thus remains as [עזְנְיָָה ['azniya].

\section{6. aḳ baba}

As another unclean bird of prey, אַ [ạ baba] appears once in Lev 11:14 of the Göz. 1841. This word stands for the Biblical Hebrew vulture; kite; red kite (milvus milvus)' (CEDHL: 112, LVTL: 198). The word ak baba was attested in Ottoman Turkish ${ }^{26}$ (RTD I: 803) and still exists in Turkish (ÖTS 1: 166), meaning 'vulture'. This compound noun might seem Turkic; ak baba lit. 'white father'. However, it is not clear whether the word was a Turkic compound originally or was later created by an analogical reformation ${ }^{27}$ from Arabic عقاب [ukāb] 'eagle', which was also present in Ottoman Turkish (OTAL: 1302). On the other hand, there are different words that stand for 'vulture' in the other Turkic languages, e.g. Az. leşyeyän qartal, Kaz. күшіген [küšigen], Kir. тарпчыл [tarpčill], Tat. улэксэ ашаучь [uläksä ašavči] (TDTLM: 65), CrTat. леш къарталь [leš ḳartali] (KRUS: 321).

In the Karaim dictionaries, the word $a k$ baba was not listed, whereas the word $а \kappa b-б а б a \kappa z y m b l$ [ak-baba kušì] 'kite' has been listed for Crimean Karaim in KRPS: 377. However, considering that the word Tָָָּ [dâ' â] is a hapax legomenon in the Hebrew Bible and was not described clearly in the Hebrew dictionaries ${ }^{28}$, it might be difficult to remark on what $a k$ baba denotes exactly in the Lev of the Göz. 1841. On the other hand, the Biblical Hebrew word has been translated with the identical Turkic form in the Ottoman Bible translations as well, e.g. Ali Bey اَقْ بَابَا 1665 [ak baba], Kieffer آق بَابًا 1827 [ak baba] 'vulture'. If the following word, čaylak, could be considered an Ottoman Turkish word (see 2.7.) that also stands for 'kite', then the word ak baba might also be accepted as a specific Ottoman Turkish word denoting 'vulture'. Finally, note that the Biblical Hebrew $d a^{\prime} a$ remains untranslated in the Lev of the CrKB.

\section{7. čaylaḳ}

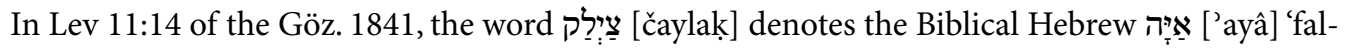
con; kite; hawk; black kite (milvus migrans)' (CEDHL: 21; LVTL: 36). The word čaylak was not attested in the Karaim dictionaries, whereas it is preserved in Turkish in an identical form, (çaylak; ÖTS 1: 908), and in Azerbaijani as çalağan (ADIL I: 439) 'kite'. In the Ottoman Bible translations,

\footnotetext{
${ }^{26}$ It must be noted that the words kerkes, kerkez, and kerkenes with the same meaning were also attested in Ottoman Turkish sources (between the $15^{\text {th }}$ and $19^{\text {th }}$ centuries) (TS IV: 2442). On the other hand, one of the earliest appearances of the word $a k b a b a$ 'vulture' is present in TLO I: 326 , which was published in 1680 (see references).

27 These two possibilities were pointed out in the Turkish dictionary (ÖTS 1: 166).

${ }^{28}$ In addition, this unclear word was also translated as 'kite' (e.g. NIV, NHEB), 'red kite' (e.g. NASB, NKJV), 'vulture' (e.g. KJB, AKJV), and 'falcon' (e.g. NLT, ESV) in some English Bible translations.
} 


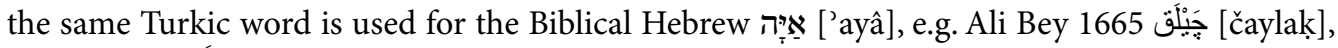

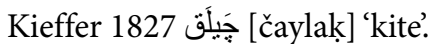

In the modern Kipchak languages, there are different words representing 'kite', e.g. Kaz. кезүқцирық [kezḳuyriḳ], Kir. айры куйрук [ayrï kuyruk], Tat. тилгән [tilgen] (TDTLM: 53), CrTat. айя [ayya] (KRUS: 42). According to Nişanyan (NS: 145-146), the word çaylak derives from the Old Turkic verb çarla-/çawla- 'to shout' together with the $+U k$ suffix, and was attested in middle Turkic Kipcak-Oghuz languages as çarlak/çawlak (see also KEWTS: 109). Although the word was not listed in Karaim dictionaries and the meaning of the Biblical Hebrew word is debated $^{29}$, it is possible to consider the word čaylak 'kite' as an Ottoman Turkish and/or Oghuzic form. In fact, the identical word is also preserved in both Ali Bey 1665 and Kieffer 1827 whereas it is not attested in the modern Kipchak languages. Thus, the meaning of the previous word ak baba can also be considered 'vulture', instead of 'kite'. On the other hand, the Lev of the CrKB once again presents the word untranslated, as aya. However, unlike the previous examples, this Biblical Hebrew word was listed in the Karaim dictionaries (for all three dialects of Karaim) as aŭa [aya] (KRPS 50-51) meaning 'kite; hawk' (CKED: 58, KRPS: 50-51). Finally, it should be noted that the same Biblical Hebrew word appears once more in Deut 14:13. Nevertheless, it was also translated as אַיזָ [aya] in the Deut of the Göz. 1841.

\section{8. ḳuzğun}

The word קוּזוּגוּנ [kuzgun] (CKED: 325, KRPS: 373) occurs once in Lev 11:15 of the Göz. 1841 and stands for the Biblical Hebrew ער ['ôrêb] 'raven; corvus' (CEDHL: 467, LVTL: 733). The same form $k u z \dot{g} u n$ is also preserved in both the CrKB and the Ottoman Bible translations (Ali Bey

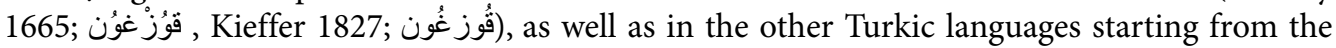
early periods with the meaning of 'raven; some black birds', e.g. IrqB: 12 kuzgun, KB: 51 kuzgin,

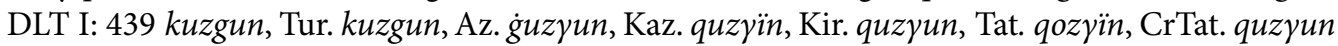
(DTMK: 162, ESTJa 6: 106-107, EDPT: 682, KEWTS: 241). Hence, both Karaim Bible translations present the same common Turkic word for this bird species.

\section{9. deve ḳušu}

Another unclean bird is present as דִ דוּ קוּשו: [deve ḳušu] (lit. 'camel bird'30) 'ostrich' (KRPS: 183) once in Lev 11:16 of the Göz. 1841, and signifies the Biblical Hebrew [ִעְנָּה ' [ya ănâ] 'female ostrich; ostrich (struthio camelus)' (CEDHL: 261, LVTL: 389). The same Turkic word with the meaning 'ostrich' was present with slight phonological differences in some Turkic languages, e.g. Tur. deve kuşu (ÖTS 2: 1185), Az. dəvaquşu (ADIL I: 606), Kaz. mүŭеұқ̧с [tüyekus] (KTS: 561), CrTat. деве къymy [deve kušu] (KRUS: 153). Among the forms, the word deve 'camel' (KRPS: 183) also shows the Oghuzic voicing of the initial $t->d$-. It is worth stressing that the word has also been attested

${ }^{29}$ In some English Bible translations, the word was translated as 'kite' (e.g. KJB, BST), 'black kite' (e.g. NIV, NHEB), 'falcon' (e.g. CSB, NAS 1977), or 'buzzard' (e.g. NETB, GWT).

30 The word might be a calque from the Persian شنر مرغ [š̈ür 'camel' murg 'bird'], which was also attested in Ottoman Turkish (RTD I: 554). 


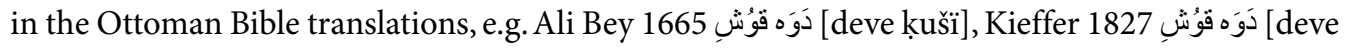
kušii] 'ostrich'.

In the $\mathrm{CrKB}$, the Biblical word was translated as aykit 'ostrich; gryphon; dragon' (CKED: 42, KRPS: 68). The same word אַגְִּקיט [anḳit] appears instead of deve kuši in Deut 14:15 of the Göz. 1841 as well, where the Biblical Hebrew word occurs for the second/last time in the whole Torah. In CKED: 42, it was remarked that the word ankit might be of Arabic origin. However, according to DTMK: 18, the word probably goes back to the Turkic añit, which denotes 'ruddy goose' (anas casarca), and later also stood for other large birds (EDPT: 176). According to Clauson, it has survived in Khakas as a:t 'black diver' (anas nigra) and in Ottoman Turkish as añt 'ruddy goose' (EDPT: 176). Nevertheless, apart from Karaim ankit, which clearly denotes a different animal species, the word still exists in some modern Turkic languages as well, e.g. Tur. angit/angut (casarca ferruginea/tadorna ferruginea) (DTMK: 18, ÖTS 1:253), Az. anqut 'rudy shelduck' (ADIL I: 119, TDTLM: 58), Trk. anq, 'rudy shelduck' (casarca ferruginea/tadorna ferruginea), Khak. aat 'the common scoter' (DTMK: 18).

\subsection{0. baya ḳušï}

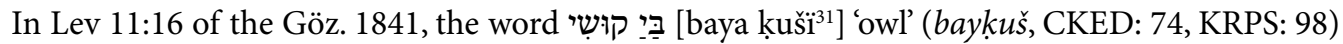
stands for the Biblical Hebrew תַחְְָ [tahmâs] 'a species of an owl (otus brucei); goat-sucker (caprimulgus)' (CEDHL: 698, LVTL: 1025). The word baykuš was also attested in many Turkic languages, e.g. Tur. baykuş, Az. bayg் 233, ESTJa 2: 32-33, EDPT: 384). According to Nişanyan (NS: 83), the compound noun consists of the Old Turkic bay 'rich' and kuş 'bird', which might be related to certain kinds of superstitions (cf. KEWTS: 81-82). In the Lev of the CrKB, the word has been translated as tahmas, which is the identical form of the Biblical Hebrew word. It is worth noting that in the Hebrew Bible, the word appears only in Lev 11:16 and Deut 14:15. However, in Deut 14:15 of the Göz. 1841, the word

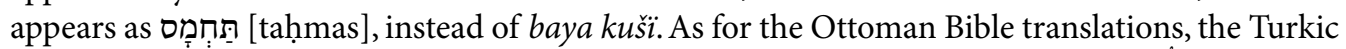
word has been used to denote the same Biblical form as well, e.g. Ali Bey 1665 بَايْقُشُش [baykuš]; Kieffer بَايقُوش [baykuš] 'owl'.

\subsection{1. ḳuḳu ḳušï}

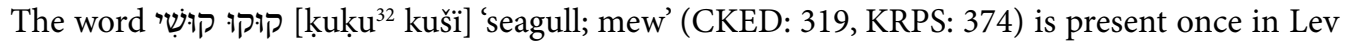
11:16 of the Göz. 1841, denoting the Hebrew שִַׁׁ [šahaf] 'seagull' (CEDHL: 650, LVTL: 961). This compound noun might seem to be a specific Karaim word since it has not been listed in commonly-known Turkic sources and it does not exist in other modern Turkic languages in the meaning of 'seagull; mew', e.g. Tur. martı, Az. qă̆аyı, Kaz. шавала [šagiala], Kir. ак чардак [ak čardak], Tat. акчарлак [akčarlak] (TDTLM: 70), CrTat. балькъчы къуш [balïkčï ḳuš]; чагъала

\footnotetext{
31 The word baya seems to be an unusual form of the word bay, which might be a scribal error. Besides this, the ending vowel in the word kuši shows another copy error (see 3.3.).

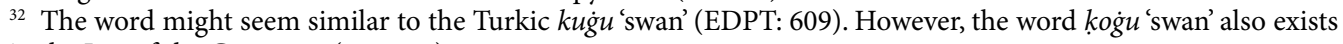
in the Lev of the Göz. 1841 (see 2.16).
} 
[čagala] (KRUS: 687) 'seagull'. However, quite interestingly the word kuḳu ḳuši also denotes the same Biblical Hebrew form in the Kieffer 1827,33 e.g. قُوقُو قُشَ [ḳuku kušì]. In Ottoman Turkish,

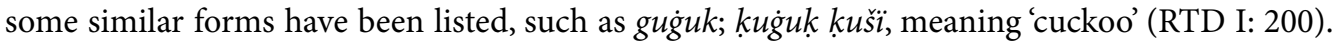
In fact, the word is onomatopoeic and was attested in early sources with different meanings, e.g. IrqB: $14 k(\ddot{a}) k \ddot{u} k$ 'eagle', DLT II: 287 kekük 'Bonelli's eagle; a bird the bones of which are used in conjurations and sorcery ${ }^{34}$ ' while in modern Turkic languages it denotes 'cuckoo', e.g. Tur. guguk kuşu, Az. $\dot{g} u \dot{g} \dot{g} u$; $\dot{g} u \gamma u$, Kir. kükük, Kaz. kökek, Tat. käkkük, CrTat. kükükquš. Considering that the Biblical Hebrew word has been translated as 'cuckoo/cuckow' in at least four different English Bible translations, e.g. KJB, AKJV, WBT, YLT, and the striking similarities between Chapter 11 of the Lev translations of the Kieffer 1827 and the Göz. 1841, it is highly possible that the word has been copied from the Ottoman Bible translation to the Göz. 1841 and therefore stands for 'cuckoo' instead of 'seagull; mew'. The main source for the Crimean Karaim kuku 'seagull; mew' definition belongs to Shapshal's ${ }^{35}$ lexical material, which has mainly been used in the KRPS dictionary. The word in the KRPS dictionary was probably collected from the Lev of the Göz. 1841 or another text (which has used the Lev of the Göz.1841 as a source) and defined based on some (probably the most common ${ }^{36}$ ) equivalents (e.g. seagull; mew) of the Biblical Hebrew word in other Bible translations (see 3.3.).

Finally, the Lev of the CrKB does not provide a Karaim translation and therefore the Biblical Hebrew šahaf has remained untranslated. Another important point is that the Biblical word is present only in Lev 11:16 and Deut 14:15 in the Tanakh. Although in Deut 14:15 of the Göz. 1841, the word was translated as שָָׁרָ [šaraf], this was probably a scribal error and goes back to the Biblical Hebrew form שַח [šahaf].

\subsection{2. dug̉an}

In Lev 11:16 of the Göz. 1841, the word דוּג [dugan] 'hawk' (yadugan/yedug்a, CKED: 440/458, KRPS 216/269) appears once and stands for the Biblical Hebrew y [nêts] 'hawk; 'falcon (falco peregrinus pelegrinoides)' (CEDHL: 423, LVTL: 628). According to Clauson (EDPT: 470-471), the word was attested as toğan in the early sources, e.g. IrqB: $12 \operatorname{tog}(a) n k u s ̧, \mathrm{~KB}: 182$ tog an 'falcon', and probably survived only in Ottoman Turkish as a generic term for 'falcon' and forms part of the names of seven or eight other related birds. In the Ottoman Bible translations, the same Turkic

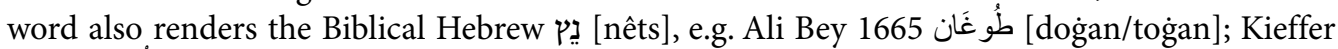
1827 [dog̉an/togan] 'hawk; falcon'. Nevertheless, in addition to the Turkish doğan (ÖTS 2:

${ }^{33}$ In the Ali Bey 1665, the same Biblical form has been translated as [ägïd]. Considering the Biblical Hebrew

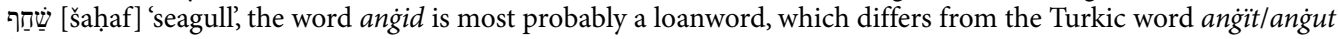
'ruddy shelduck'.

${ }^{34}$ According to EDPT 710, the identity of the word is uncertain. However, Hauenschild claims that Kashgari's translation al-zummağ stands for 'cuckoo', whereas it is often mistakenly considered to be 'sparrow-hawk' or 'merlin' (see DTMK: 101).

35 Seraya Shapsal (1873-1961) was an orientalist scholar and the last hakham (the highest spritual authority in the Karaim community) of the East European Karaims who played a important role in the Turkicization of Karaim ethnic identity and the language. He is one of the co-authors of the KRPS dictionary and made a large number of studies on Crimean Karaim (For further details, see e.g. Shapira 2005, Kizilov 2009: 235-277).

${ }^{36}$ In at least 19 English Bible translations, the Hebrew word has been translated as 'sea-gull', 'gull', or 'sea-mew', e.g. NKJV, CSB, ISV, NAS 1977, etc. 
1257), it is still preserved in other modern Turkic languages as well, e.g. Gag. doan, dyjan, Nog., Kaz. tujyyun, HKar. tuyan, Uyg. toyan, Yak. tojon (ESTJa 3: 247, L: 169, KEWTS: 130). Note that the word dugan in the Lev of the Göz. 1841 shows the Oghuzic feature of the voicing of the initial $t->d$ - as well.

In the Lev of the CrKB, the word was translated as kirgïy (CKED: 304, KRPS: 381), meaning 'hawk'. In the entire Torah, the Biblical Hebrew word was also attested in Gen 40:10 and Deut 14:15. In Gen 40:10 it denotes 'blossom', whereas in Deut 14:15 it indicates the bird species which appears as קִירְִגי [kïgïy] in the Göz. 1841, similar to the Lev of the CrKB example. According to Clauson (EDPT: 654-655), the word kırğuy 'sparrow-hawk' (accipiter nisus) was not attested in Ottoman Turkish, whereas it exists in the early sources, e.g. DLT II: 95 kırguy, CC: 207 qyryyj

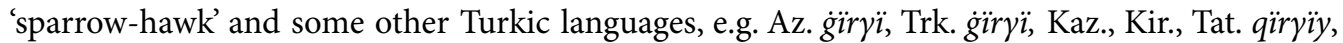
CrTat. girryïy 'sparrow; Eurasian sparrow-hawk' (DTMK: 132, ESTJa 6: 234). Thus, it is possible to say that the Lev of the Göz. 1841 once again presents a specific word that was common in Ottoman Turkish, whereas the Lev of the CrKB employs a word that is used in many Turkic languages except for Ottoman Turkish.

\subsection{3. ügi ḳušu}

The word אוּגִי קוּשו: [ügi ${ }^{37}$ ḳušu] 'eagle owl' (ug̈̈̈y, CKED: 424, KRPS: 573) occurs once in Lev 11:17 of the Göz. 1841, and stands for the Biblical Hebrew סiּ [kôs] 'little owl; owlet (athene noctua saharae)' (CEDHL: 273, LVTL: 428). The word ügi 'owl' was attested in many early texts, e.g. KB: 246, DLT I: $9 \ddot{u} g i$, CC: 269 ügü 'owl', and Turkic languages, e.g. Tur. puhu, Trk. $\chi \ddot{u} v i$, Kaz. üki, Kir. ükü, CrTat. puүu 'owl; eagle owl' (DTMK: 232, TMEN II: 612, L: 170, EDPT: 101). Nevertheless, in the Lev of the CrKB, the word has remained as kos. In the whole Torah, the Biblical Hebrew word appeared altogether 6 other times, e.g. Gen 40:11/13/21, Deut 14:16. In Gen, the word denotes 'cup', whereas in Deut 14:16 it also stands for the bird species. However, Deut 14:16 of the Göz. 1841 presents the word as כּ כ [kos], unlike ügi ḳušu in the Lev of the Göz. 1841. Finally, it must be pointed out that similar Turkic forms were preserved in Ottoman Bible translations as well, e.g.

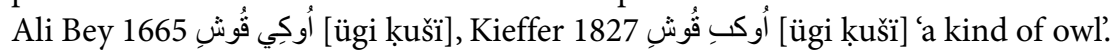

\subsection{4. ḳara batak}

Another unclean bird appears as קַרַא בַַַּ [ḳara batak] in Lev 11:17 of the Göz. 1841, and stands for the Biblical Hebrew שָָָׁ [šalâk], denoting a bird of uncertain meaning ${ }^{38}$ that is rendered by most scholars as 'cormorant', or also as 'fish owl' (ketupa ceylonensis) (CEDHL: 662, LVTL: 978). The word kara-batak exists in the best-known Karaim dictionaries (for Crimean Karaim) as 'tern' (CKED 290, KRPS: 363), whereas it was also referred to as 'cormorant' (TDTLM: 39) ${ }^{39}$. The exact word has been attested in Ottoman Turkish (RTD I: 180) in the written sources since the $16^{\text {th }}$

\footnotetext{
37 Due to the Hebrew script form, it is also possible to read the word as $u \ddot{g} \ddot{i}$.

38 In some English translations it has been translated as 'cormorant' (e.g. ESV, KJB, etc.), whereas 'fisher owl' (e.g. NKJV) and 'gannet' (e.g. DBT) can also be found.

${ }^{39}$ The source does not make distinction between Eastern and Western Karaim.
} 
century $^{40}$, and is still preserved in Turkish as karabatak (ÖTS 3:2413), and in Azerbaijani as qarabatdaq (ADIL Vol.3: 47) 'cormorant'. In fact, the word karabatak is also present in the Ottoman

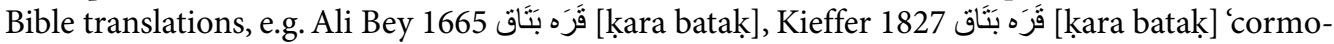
rant'. Nonetheless, there exist different words for this bird species in the other Turkic languages, e.g. Trk. жуптун [žüptün], Kaz. баклан [baklan], Kir. кара каз; каракаш [kara kaz; karakaš], Tat. дингез козгыны [dingäč kozïinii] (TDTLM: 39), CrTat. далгъыч къуш [dalg̈ič kuš] (KRUS: 150). The word kara batak consists of two Turkic elements: kara 'black' and batak 'bog'. Although batak stands for 'bog' in Turkish, the form most probably goes back to batığ/batu 'act of sinking' (EDPT: 301, ESTJa 2: 80), which might refer to the cormorant diving for its prey. In fact, the Kipchak counterpart batuk has also been attested in KI: 16 as 'cormorant'. However, the form kara batak does not occur in the other modern Turkic languages and well-known early sources. Thus, the Lev of the Göz. 1841 presents an Oghuzic/Ottoman Turkish lexical form for this bird species, unlike the Lev of the CrKB, which shows the untranslated Biblical Hebrew form šala . It is important to note that the Biblical Hebrew word also appears once in Deut 14:17, which appears as [šala $]$ in the Deut of the Göz. 1841, identical to the Biblical Hebrew form.

\subsection{5. toyï}

The word טוֹיי [toyi] 'ibis' (CKED: 410, KRPS: 535) occurs once in Lev 11:17 of the Göz. 1841, and denotes the Biblical Hebrew יִּנְוּף [yanšuf] 'long-eared owl' (asio otus); bee-eater (merops apiaster)' (CEDHL: 260, LVTL: 386). The word toyï seems to be a unique word, which has not been attested in the other Turkic sources with the meaning of 'ibis'. However, a phonetically similar form might be the Ottoman Turkish toy 'bustard' (RTD I: 103, TS V: 3833), which also survives in modern Turkish, e.g. toy; toy kuşu 'great bustard' (otis tarda) (ÖTS 5: 4882). According to Clauson (EDPT: 449), the earlier form of toy 'bustard' goes back to tod and probably only survived in Ottoman Turkish; it was also attested in KB: 534, DLT III: 142, toy 'bustard'. Nevertheless, the word toyi in the corpus clearly denotes a different bird species, since in Crimean Karaim 'bustard' has been denoted by duvada $k^{41}$ (CKED: 143, KRPS: 180), which is a different variant of the word toy and similar 'bustard' translations do not appear for this Biblical Hebrew word in Bible translations. However, with the help of the Ottoman Bible translations, light can be shed on the mystery of this Karaim word. In both Ali Bey 1665 and Kieffer 1827, the same Biblical Hebrew word has been translated as $t o / t u^{42}$, meaning 'a species of owl'. ${ }^{43}$ At the same time, the Oghuzic ACC marker +(y)I has been attached to both of the words, e.g. Ali Bey توُِي 1665 [to/tu+yï]; Kieffer 1827 [to/tu+yi]. Thus, Karaim toyi 'ibis' seems another copy mistake which occurred in Lev 11 of the

40 According to Nişanyan (NS: 413), the word has been attested in Regola del Parlare Turco, which was written by Filippo Argenti in 1533 (see references).

${ }^{41}$ Similar forms exist in the other modern Turkic languages as well, e.g. Az. doydag, Trk. toydarï, Kaz. duwadaq, Kir. toodaq, Tat. düdäk (DTMK: 224, TMEN II: 519-527, L: 174), CrTat. дувадакъ [duvadak] (KRUS: 168) 'great bustard'.

42 Due to the Arabic script, the word can be read in two different ways.

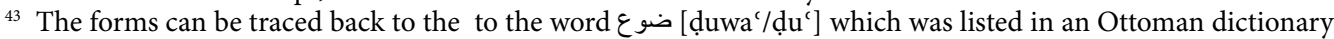
from the 17th century in the meaning of 'male owl (bubo mas); black bird (avis nigra)' (TLO II: 3055). Similar meanings were also listed in both Arabic and Persian dictionaries as well, e.g. ضوع; 'a species of owl; an owl' (WAED: 372, CPED: 804). 
Göz. 1841. Similar to the previous example (see 2.11), it might be possible to consider that the meaning of this problematic word has been giving according to an equivalent of the original Biblical Hebrew word in other Bible translations ${ }^{44}$. On the other hand, in the Lev of the CrKB, the word appears in a form identical to the Biblical Hebrew word, yanšuf. Additionally, the word has

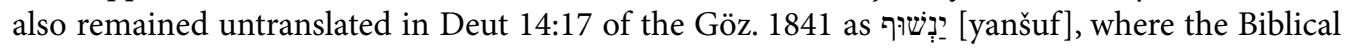
Hebrew word occurs for the second/last time in the entire Torah.

\subsection{6. koğu}

The word קוגוג [kogu] 'swan' (CKED: 310, KRPS: 318) is present once in Lev 11:18 of the Göz. 1841, and denotes the Biblical Hebrew תִּנְשֶמת [tinšemet], which stands for two different animals. The first one is a kind of owl, probably 'white owl' (tyto alba), whereas the other one is 'chameleon' (CEDHL: 709, LVTL: 1035). However, the word $k o g \dot{u}$ clearly denotes a different animal ${ }^{45}$, which appears in many Turkic sources, e.g. IrqB: 16 kugu kuş, KB: 24 kugi $u$, DLT III: 225 kugu, and Turkic languages with some phonological changes, e.g. Tur. kuğu, Az. $\dot{g} u$, Trk. $\dot{g} u v$, Kaz. aqqu, Kir. $q u u$, Tat. aqqoš, CrTat. aqqu (DTMK: 148, EDPT: 609, TDTLM: 55, KRUS: 45). The Kieffer $1827^{46}$ also presents the word قُو فُو $[\mathrm{kugu}$ ] for this translation, whereas the Biblical form has remained untranslated as tinšemet in the Lev of the CrKB. It must be noted that the Biblical Hebrew word is present altogether 3 times in the whole Tanakh. Although it has been translated as göz töbä in

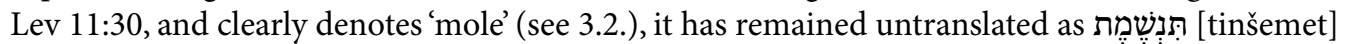
in Deut 14:16 of the Göz. 1841, just as with the Lev of the CrKB example.

\subsection{7. ḳašīḳčï ḳušï}

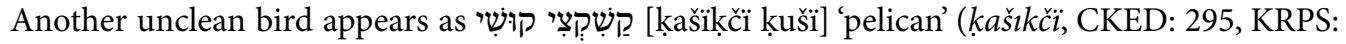
368) once in Lev 11:18 of the Göz. 1841, denoting the Biblical Hebrew קָָּ [qấat], which indicates 'pelican', although some scholars believe that it might also mean 'little owl' (athene noctus lilith) or 'jackdaw' (CEDHL: 559, LVTL: 819). The word kašik 'spoon' (CKED: 295, KRPS: 368) most probably refers to the pelican's characteristic beak. Slightly different forms were also attested in Ottoman Turkish as kaşık burun (lit. 'spoon nose') (TS IV: 2329) and in Crimean Tatar as

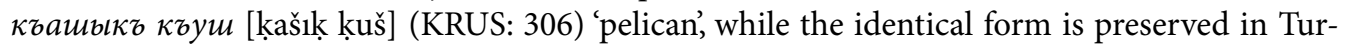
kish as kaşı kçı kuşu 'pelican' (ÖTS 3: 2464). Similar to the previous examples, the Ottoman Bible translations and the Göz. 1841 show parallels in Chapter 11 of the Lev, e.g. Ali Bey 1665 قَاثقِقِي

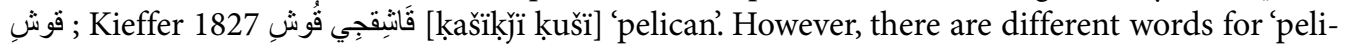
can' in the other Turkic languages, e.g. Az. qutan; balıqudan, Trk. готан [gotan], Kaz. бірқазан [birḳazan], Kir. биргазан [birgazan], Tat. баба кош [baba koš] (TDTLM: 59). As for the Lev of the

\footnotetext{
${ }^{44}$ It should be pointed out that in at least 20 different English Bible translations the word was translated as 'a species of owl', (e.g. NIV, KJB, NASB, etc.) whereas it appears as 'ibis' only in a few of them (e.g. ISV, DRB, DBT).

${ }_{45}$ This Biblical Hebrew word has denoted different animal species in some English Bible translations as well, e.g. 'swan' (e.g. AKJV, BST, etc.), 'white owl' (e.g. BSB, NASB, etc.) 'barn owl' (e.g. NLT, ESV, etc.), 'water-hen' (e.g. ISV), 'horned-owl' (e.g. ASV, ERV, etc.), 'red-bill' (e.g. BST, etc.).

46 In the Ali Bey 1665, the word سَقَسَغَن [saksagan] 'magpie' (RTD I: 495) has been used.
} 
$\mathrm{CrKB}$, the word has remained untranslated and therefore appears as $k a^{\prime} a t$. In the whole Torah, the same word also appeared in Deut 14:17. However, in the Deut of the Göz. 1841, the word appears as קָָָ [kahat], similar to the Biblical Hebrew form.

\subsection{8. raḥamï}

Another unclean bird appears as רַחמִמִ [rahamï] in Lev 11:18 of the Göz. 1841, and goes back to

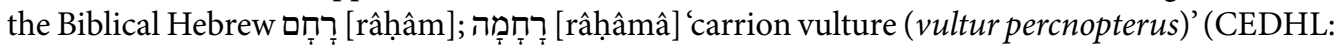
613, LVTL: 886). The word has remained untranslated in the Lev of the CrKB as well, e.g. rahama. Furthermore, this uncertain word ${ }^{47}$ appeared as jَخ jah(a)m] in the Kieffer $1827^{48}$ as well, which might explain why it has also remained untranslated in the Göz. 1841, which is not usual for Chapter 11 of its Lev translation. In addition, it seems that the word rahami shows another copy mistake, which includes one of the Oghuzic ACC markers $+(y) I$ (see 3.3.). It is also worth noting that the word appears as רִחַמָה [rahama] in Deut 14:17 of the Göz. 1841 as well, where the Biblical Hebrew word occurs for the second/last time in the whole Hebrew Bible.

\subsection{9. legläg}

The word לִגְּל [legläg] 'stork' (leglek, CKED: 229; leklek, KRPS: 400) in Lev 11:19 of the Göz. 1841 stands for the Biblical Hebrew חִ חַידָה [hăsîdâ], which indicates 'stork; heron' (CEDHL: 225, LVTL: 319). The similar forms were attested in the Ottoman Bible translations as well, e.g. Ali Bey 1665 لَيَْكَ [leyleg/leylek], Kieffer 1827 لَكلَك [legleg/leklek]. The word legläg is of Arabic origin (NS: 506), and is preserved in many modern Turkic languages as well, e.g. Tur. leylek, Az. leyläk, Kaz. ләйлек [läylek], Kir. илегилек [ilegileg], Tat. ләкләк [läkläk] (TDTLM: 39), CrTat. лейлек [leylek] (KRUS: 320). However, in the Lev of the CrKB, it appears as hasida, which is identical to the Biblical Hebrew word. In the rest of the Torah, the same word also appears once in Deut. 14:17. Similar to the previous examples, in the Deut of the Göz. 1841, the word has remained untranslated, e.g. חִסִסידָה [hasida], unlike the Lev of the Göz. 1841.

\subsection{0. balïḳciin}

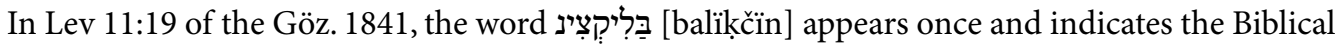
Hebrew אָָָָּּ ['ănâfâ] 'heron; egret' (CEDHL: 41, LVTL: 70). In Karaim, the word balikčìn has not been listed, whereas the word turna (CKED: 414, KRPS: 548) means 'heron; crane' in Crimean and Halitch Karaim. On the other hand, the Biblical Hebrew אִנָָָּ ['ănâfâ] has been denoted using

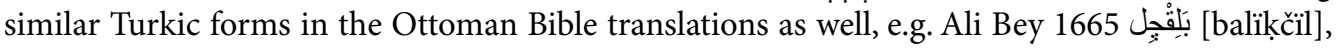
Kieffer 1827 بَالقِقِين [balikkčìn] 'heron'. According to Clauson (EDPT: 337), the word balıkçın 'heron;

${ }_{47}$ The word was translated in some English Bible translations as 'osprey' (e.g. NIV, BSB, etc.), 'Egyptian vulture' (e.g. NLT), 'carrion vulture' (e.g. ESV, NKJV, etc.), 'gier-eagle' (e.g. KJB, JB2000, etc.), 'vulture' (e.g. ASV, ERV), 'swan' (e.g. BST), and 'porphyrion' (e.g. DRB).

${ }_{48}$ In the Ali Bey 1665, the word has been translated as قُو فُو [kugu] 'swan'. 
fish-eating bird', which also appeared in DLT I: 512, probably only survived in Ottoman Turkish (TS I: 390). However, apart from Turkish balıkçıl (ÖTS 1: 452) and Crimean Tatar бальıъъиль [balikčil] (KRUS: 95) 'heron; egret', the word was attested with slight phonological differences in some modern Turkic languages referring to different bird species, e.g. Uzb. balïqci ' 'seagull', Khak. palï či 'cormorant' (DTMK: 55); in contrast, there are different words for 'heron' in the other Turkic languages, e.g. Az. balıqudan; vă̆, Trk. хокгар; сувгушы [hokgar; suvğuši], Kaz. кеккутан [kekkutan], Kir. кытан [kïtan], Tat. челэн [čelän] (TDTLM: 69). On the other hand, in the Lev of the CrKB, the word anafa has remained untranslated as per the Biblical Hebrew form. In the Hebrew Bible, the same word also appeared for a second/last time in Deut 14:18. However, once again the word has remained untranslated in the Deut of the Göz. 1841, e.g. אָנָָָָּ [anafa].

\subsection{1. hüd hüdi}

Lev 11:19 of the Göz. 1841, presents the word hiוּד הוּדִי [hüdi' ${ }^{49}$ ] to render the Biblical Hebrew דּוּכִיפַת [dûkîfat] 'hoopoe' (CEDHL: 117, LVTL: 205). The word has not been listed in the Karaim dictionaries, whereas it was attested in the Ottoman Bible translations, e.g. Ali Bey 1665 هُهُ [hüdhüd], Kieffer 1827 هُدُدُ [hüdhüd], as an Arabic loanword (NS: 348). In modern Turkic languages, this word exists in the Oghuz branch, Tur. hüthüt, Az. hüdhüd 'hoopoe', whereas Kipchak languages have different words that stand for 'hoopoe', e.g. Kaz. ұдyұ; сасыю кекек [üdüd; sasïk kekek], Kir. YnYn; cacbı $\eta^{n}{ }^{n}$ [üpüp; sasïk üpüp] ${ }^{50}$, Tat. ведйэд кошьь [bedyed koši] (TDTLM: 68). However, in the Lev of the CrKB, the Biblical Hebrew has remained untranslated, e.g. duxifat, which is also present in Deut 14:18 of the Göz. 1841 as [וּכִיפָת [duxifat], where the Biblical Hebrew word appears for the second/last time in the entire Hebrew Bible. Thus, the Lev of the Göz. 1841 presents another Arabic loanword that existed in the Oghuzic area, unlike the Deut of the Göz. 1841 and the Lev of the CrKB.

\subsection{2. tor}

In the whole of the Lev of the Göz. 1841, there exist nine instances that denote the Biblical Hebrew ת ת [tôr] 'turtle-dove (streptopelia turtur); other species of columba' (CEDHL: 695, LVTL: 1023). As was noted above (see 2.2), eight out of these nine times it was written as kumru, whereas one example in Lev 14:30 of the Göz. 1841 displays the Biblical Hebrew form רiภ [tor]. Conversely, it was always translated as tor in the Lev of the CrKB. The word also appears once in the Gen and the Num of the Torah. However, in the rest of the Göz. 1841, the word tor never appears, כוּמְרִ 15:9

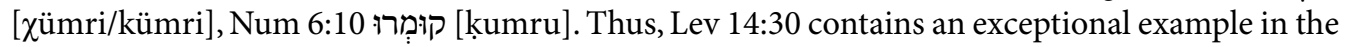
Göz. 1841, showing more than one lexical item (that is not given in parenthesis) for the same bird species throughout the Lev.

\footnotetext{
49 The word can also be read as hudhudi.

50 The form üpüp goes back to the Old Turkic onomatopoeic word üpgük, which has been attested in many early written Turkic sources, e.g. IrqB: 14 üpgük, DLT I: 78 übgük 'hoopoe’ and Turkic languages, e.g. Tur. ibibik, Az. hophop, Trk. xüypüypik, CrTat. öpöpö 'hoopoe’ (DTMK: 234, KEWTS: 181).
} 


\section{CONCLUSION}

\subsection{The distribution of the bird names in the corpus}

In this study, the bird names appearing in the Lev of the Göz. 1841 have been presented together with their equivalents in the Lev of the CrKB, the Ali Bey 1665, and the Kieffer 1827. Although the languages of the Göz. 1841 and the CrKB were assumed to be similar, their lexicons for the bird names in the Lev show quite many differences, since out of 21 different bird names, only five words $(24 \%)$ occur in similar forms in these two Bible translations.

Table 1. The common bird names in the Lev of the Göz. 1841 and the CrKB

\begin{tabular}{|c|c|c|c|}
\hline Lev & Biblical Hebrew Forms & Göz. 1841 & CrKB \\
\hline $\begin{array}{l}1: 14,14: 30 \\
12: 6,5: 7\end{array}$ & 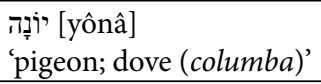 & $\begin{array}{l}\text { kög̈ürčin/kögürčün/gügürč̌in/gögürčün } \\
\text { 'pigeon' }\end{array}$ & \begin{tabular}{|l|}
$\begin{array}{l}\text { kögürčgün } \\
\text { 'pigeon' }\end{array}$ \\
\end{tabular} \\
\hline 11:13 & 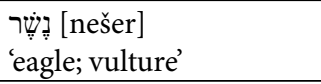 & kara kuš 'eagle' & kara kuš 'eagle' \\
\hline 11:15 & ער ['ôrêb] 'raven' & kuzg்un 'raven' & kuzg்un 'raven' \\
\hline $11: 18$ & $\begin{array}{l}\text { 'carrion vulture' } \\
\text { 'câhâm] }\end{array}$ & rahamï (untranslated Biblical form) & $\begin{array}{l}\text { rahama } \\
\text { (untranslated Biblical } \\
\text { form) }\end{array}$ \\
\hline $14: 30$ & $\begin{array}{l}\text { רiֹ [tôr] } \\
\text { 'turtle-dove' }\end{array}$ & tor (untranslated Biblical form) & $\begin{array}{l}\text { tor (untranslated Bibli- } \\
\text { cal form) }\end{array}$ \\
\hline
\end{tabular}

Among these examples, the words tor and rahamï/rahama go back to the Biblical Hebrew forms, whereas the other three words are of Turkic origin. It is remarkable that the bird names in the Lev of the $\mathrm{CrKB}$ consist of a high predominance of Biblical Hebrew words. As has been discussed, the main reason for this might be related to the uncertainty of some Biblical Hebrew words for animal names in the Hebrew Bible. The Lev of the CrKB presents altogether 21 different bird names, and 16 of these words (76\%) are from the Biblical Hebrew forms, e.g. tor'turtle-dove', peres 'bearded vulture', 'azniya 'black vulture', da' a 'eagle; vulture; kite; red kite', aya 'falcon; kite; hawk; black

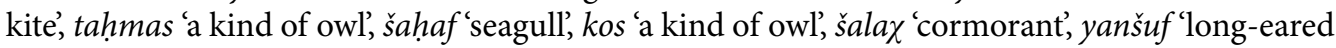
owl; bee-eater', tinšemet 'white owl; chameleon', $k a$ ' at 'pelican; little owl; jackdaw', rahama 'carrion vulture', hasida 'stork', anafa 'heron; egret', duxifat 'hoopoe', and 5 of them (24\%) are of Turkic origin, e.g. kögürčün 'pigeon', kara kuš 'eagle', kuzg்un 'raven', kïrğïy 'hawk', aykït 'ostrich'. Among these Turkic items, the Lev of the CrKB only shows two common Turkic forms (14\%) that were also attested in similar forms in Ottoman Turkish, e.g. kögürčgün 'pigeon', karakuš 'eagle'. Thus, it should be noted that the CrKB edition does not present any specific Oghuzic and/or Ottoman Turkish forms for the bird names throughout the Lev.

In the Lev of the Göz. 1841, only two items (9\%) out of 23 different bird names come from to the Biblical Hebrew forms, e.g. rahami 'carrion vulture', tor 'turtle-dove'. In the other cases, there are 15 Turkic words (65\%), e.g. kögürčin/kögürčün/gügürčin/gögürčün 'pigeon', kartal; kara kuš 'eagle', deyiz kartali 'sea-eagle', ak baba 'vulture', čaylak ' kite', kuzgun 'raven', deve kušu 'ostrich', baya

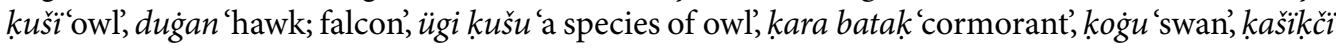
kuši 'pelican', balikčìn 'heron', three words (13\%) are of Arabic origin that were common in Otto- 
man Turkish, e.g. kumru 'turtle-dove', legläg 'stork', hüd hüdi 'hoopoe', and one lexical item (4\%) is of Persian origin, e.g. ironi 'bearded vulture' (gypaetus barbatus). Although the rest of the examples (9\%) were listed in the Karaim dictionaries, e.g. toyï 'ibis', kuku kuši 'seagull', it seems they were copied from the Kieffer 1827 with some morphological mistakes. Nevertheless, it is possible to claim that 15 bird names were directly/indirectly influenced by the specific Ottoman Turkish lexicon (65\%, see Table 2). Therefore, the Lev of the Göz. 1841 and the CrKB demonstrate a clear difference regarding the use of specific Ottoman Turkish words for the bird names (65\% vs 0\%).

Table 2. The specific Ottoman Turkish words in the Lev of the Göz. 1841

\begin{tabular}{|c|c|c|c|c|}
\hline Lev & $\begin{array}{l}\text { Biblical Hebrew } \\
\text { Forms }\end{array}$ & Göz. 1841 & Kieffer 1827 & Ali Bey 1665 \\
\hline $5: 7 / 12: 6$ & 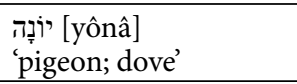 & gügürčin/gögürčün 'pigeon' & $\begin{array}{l}\begin{array}{l}\text { gögerjin } \\
\text { 'pigeon' }\end{array} \\
\end{array}$ & $\begin{array}{l}\text { gögerjin } \\
\text { 'pigeon' }\end{array}$ \\
\hline $5: 7$ & $\begin{array}{l}\text { 'ת [tôr] } \\
\text { 'turtle-dove' }\end{array}$ & \begin{tabular}{|l|} 
kumru \\
'turtle-dove'
\end{tabular} & $\begin{array}{l}\text { kumru } \\
\text { 'turtle-dove' }\end{array}$ & $\begin{array}{l}\text { kumru } \\
\text { 'turtle-dove' }\end{array}$ \\
\hline $11: 13$ & 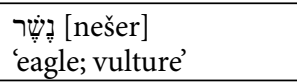 & \begin{tabular}{|l|} 
kartal \\
'eagle' \\
\end{tabular} & \begin{tabular}{|l|} 
kartal \\
'eagle'
\end{tabular} & $\begin{array}{l}\text { kartal } \\
\text { 'eagle' }\end{array}$ \\
\hline $11: 13$ & $\begin{array}{l}\text { עִ עִ ['oznîyâ] } \\
\text { 'black vulture' }\end{array}$ & $\begin{array}{l}\text { deniz kartali } \\
\text { prob. 'sea-eagle' }\end{array}$ & $\begin{array}{l}\begin{array}{l}\text { deniz kartali } \\
\text { 'sea-eagle' }\end{array} \\
\end{array}$ & $\begin{array}{l}\text { deniz kartali } \\
\text { 'sea-eagle' }\end{array}$ \\
\hline $11: 13$ & $\begin{array}{l}\text { פִ [peres] } \\
\text { 'bearded vulture' }\end{array}$ & $\begin{array}{l}\text { ironï } \\
\text { prob.'a kind of eagle' }\end{array}$ & \begin{tabular}{|l|} 
iron/irun \\
'a kind of eagle'
\end{tabular} & $\begin{array}{l}\text { eron } \\
\text { 'a kind of eagle' }\end{array}$ \\
\hline $11: 14$ & $\begin{array}{l}\text { lạ [dâ'â] } \\
\text { 'eagle and/or vulture; } \\
\text { kite; red kite' }\end{array}$ & $\begin{array}{l}a k b a b a \\
\text { prob. 'vulture' }\end{array}$ & $\begin{array}{l}a k b a b a \\
\text { 'vulture' }\end{array}$ & $\begin{array}{l}a k b a b a \\
\text { 'vulture' }\end{array}$ \\
\hline $11: 14$ & $\begin{array}{l}\text { אִ ['ayâ] } \\
\text { 'falcon; kite; hawk; } \\
\text { black kite' }\end{array}$ & $\begin{array}{l}\text { čaylak } \\
\text { prob. 'kite' }\end{array}$ & $\begin{array}{l}\text { čaylak } \\
\text { 'kite' }\end{array}$ & $\begin{array}{l}\text { čaylak } \\
\text { 'kite' }\end{array}$ \\
\hline $11: 16$ & 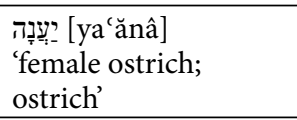 & $\begin{array}{l}\text { deve kušu } \\
\text { 'ostrich' }\end{array}$ & $\begin{array}{l}\text { deve kuši } \\
\text { 'ostrich' }\end{array}$ & $\begin{array}{l}\text { deve kuši } \\
\text { 'ostrich' }\end{array}$ \\
\hline $11: 16$ & 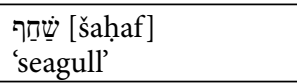 & 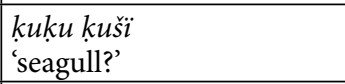 & ḳuḳu ḳuši 'cuckoo' & $\begin{array}{l}\text { angït } \\
\text { (undefined word) }\end{array}$ \\
\hline $11: 16$ & $\begin{array}{l}\text { ני [nêts] } \\
\text { 'hawk; falcon' }\end{array}$ & \begin{tabular}{|l} 
dugian \\
'hawk; falcon'
\end{tabular} & $\begin{array}{l}\text { dog்an } \\
\text { 'hawk; falcon' }\end{array}$ & $\begin{array}{l}\text { doġan } \\
\text { 'hawk; falcon' }\end{array}$ \\
\hline $11: 17$ & 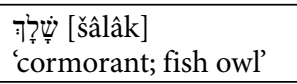 & \begin{tabular}{|l|} 
kara batak \\
'tern?'
\end{tabular} & $\begin{array}{l}\text { kara batak } \\
\text { 'cormorant' }\end{array}$ & $\begin{array}{l}\text { kara batak } \\
\text { 'cormorant' }\end{array}$ \\
\hline $11: 17$ & 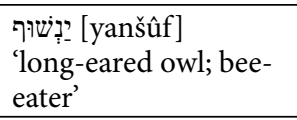 & $\begin{array}{l}\text { toyï } \\
\text { 'ibis?' }\end{array}$ & $\begin{array}{l}\text { to/tu } \\
\text { 'a species of owl' }\end{array}$ & $\begin{array}{l}\text { to/tu } \\
\text { 'a species of owl' }\end{array}$ \\
\hline 11: 18 & 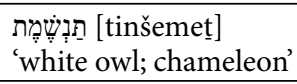 & \begin{tabular}{|l|}
$k o \dot{g} u$ \\
iswan \\
\end{tabular} & \begin{tabular}{|l|l|}
$k u \dot{g} u$ \\
'swan'
\end{tabular} & saksaġan 'magpie' \\
\hline $11: 18$ & $\begin{array}{l}\text { קָ [qẩaț] } \\
\text { 'pelican; little owl; } \\
\text { jackdaw' }\end{array}$ & $\begin{array}{l}\text { kašïkči kuši } \\
\text { 'pelican’ }\end{array}$ & $\begin{array}{l}\text { kašıkji kuši } \\
\text { 'pelican' }\end{array}$ & $\begin{array}{l}\text { kašk kjü kuši } \\
\text { 'pelican' }\end{array}$ \\
\hline $11: 19$ & 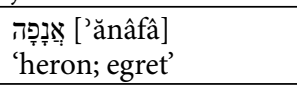 & $\begin{array}{l}\text { balikčìn } \\
\text { prob. 'heron' }\end{array}$ & balikčïn 'heron' & balikčill 'heron' \\
\hline 11:19 & 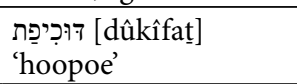 & $\begin{array}{l}\text { hüd hüdi } \\
\text { prob.'hoopoe' }\end{array}$ & $\begin{array}{l}\text { hüdhüd } \\
\text { 'hoopoe' }\end{array}$ & $\begin{array}{l}\text { hüdhüd } \\
\text { 'hoopoe' }\end{array}$ \\
\hline
\end{tabular}


In conclusion, except for the untranslated Biblical Hebrew forms, (e.g. tor 'turtle-dove', rahami 'carrion vulture'), the remaining words of the lexicon for the bird names (91\%) in the Lev of the Göz. 1841 are predominantly similar to the words in Ottoman Turkish and/or the Oghuzic languages. Based on the comparison, it is quite clear that the main source for the bird names in Lev 11 of the Göz. 1841 was the Kieffer 1827, since all the words that stand for the bird species in Lev 11 of these translations are identical or extremely similar. ${ }^{51}$ Another finding also supports this claim, since 16 of the 23 bird names (70\%) were attested in the other books (Pentateuch) of the Göz. 1841 in different forms, and are almost identical to the Lev of the CrKB examples. However, these parallel forms are mostly based on untranslated Biblical Hebrew forms.

Table 3. The comparison of the other Books of the Göz. 1841

\begin{tabular}{|c|c|c|c|}
\hline Biblical Hebrew Forms & $\begin{array}{l}\text { Lev of the } \\
\text { CrKB }\end{array}$ & Other Books of the Göz. 1841 & $\begin{array}{l}\text { Lev of the Göz. } \\
1841\end{array}$ \\
\hline $\begin{array}{l}\text { נֶֶֶ [nešer] } \\
\text { 'eagle; vulture' }\end{array}$ & 11:13, ḳarakuš & $\begin{array}{l}\text { Exo 19:4, Deut 14:12, 28:49, 32:11, } \\
\text { karakuš }\end{array}$ & $\begin{array}{l}\text { 11:13, } \\
\text { kartal/kara kuš }\end{array}$ \\
\hline $\begin{array}{l}\text { פִר [peres] } \\
\text { 'bearded vulture' }\end{array}$ & 11:13, peres & Deut 14:12, peres & $\begin{array}{l}\text { 11:13, } \\
\text { ironï }\end{array}$ \\
\hline $\begin{array}{l}\text { עִ עִ עִ ['oznîyâ]] } \\
\text { 'black vulture' }\end{array}$ & 11:13, 'azniya & Deut 14:12, 'azniya & $\begin{array}{l}11: 13, \\
\text { deyiz kartali }\end{array}$ \\
\hline $\begin{array}{l}\underline{n} \text { ['ayâ]] } \\
\text { 'falcon; kite; hawk; black kite' }\end{array}$ & $11: 14$, aya & Deut 14:13, aya & $\begin{array}{l}\text { 11:14, } \\
\text { čaylak }\end{array}$ \\
\hline $\begin{array}{l}\text { ' [ya ănâ] } \\
\text { 'female ostrich; ostrich' }\end{array}$ & 11:16, ankït & Deut 14:15, aykit & $\begin{array}{l}\text { 11:16, } \\
\text { deve kuši }\end{array}$ \\
\hline $\begin{array}{l}\text { Oת [tahmâs] } \\
\text { 'a species of an owl' }\end{array}$ & 11:16, tahmas & Deut 14:15, tahmas & $\begin{array}{l}\text { 11:16, } \\
\text { baya kušï }\end{array}$ \\
\hline 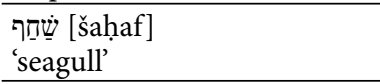 & 11:16, šahaf & Deut 14:15, šaraf & $\begin{array}{l}\text { 11:16, } \\
\text { kuku kušï }\end{array}$ \\
\hline $\begin{array}{l}\text { נnêts] } \\
\text { 'hawk; falcon' }\end{array}$ & 11:16, kïrg̈̈̈y & Deut 14:15, kïrğïy & $\begin{array}{l}\text { 11:16, } \\
\text { duġan }\end{array}$ \\
\hline $\begin{array}{l}\text { oị [kôs] } \\
\text { 'a kind of owl' }\end{array}$ & $11: 17$, kos & Deut 14:16, kos & $\begin{array}{l}\text { 11:17, } \\
\text { ügi kušu }\end{array}$ \\
\hline 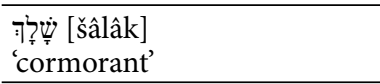 & $11: 17$, šala & Deut 14:17, šala & $\begin{array}{l}\text { 11:17, } \\
\text { kara batak }\end{array}$ \\
\hline 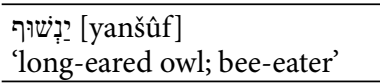 & 11:17, yanšuf & Deut 14:17, yanšuf & $\begin{array}{l}11: 17 \\
\text { toyi }\end{array}$ \\
\hline $\begin{array}{l}\text { ת ת [tinšemeț } \\
\text { 'white owl } \\
\end{array}$ & $11: 18$, tinšemet & Deut 14:16, tinšemet & $\begin{array}{l}11: 18 \\
\text { kog்u }\end{array}$ \\
\hline $\begin{array}{l}\text { קִ [qâat] } \\
\text { 'pelican; little owl; jackdaw' }\end{array}$ & $11: 18, k a^{3} a t$ & Deut. 14:17, kahat & $\begin{array}{l}\text { 11:18, } \\
\text { kašĭkči kušu }\end{array}$ \\
\hline 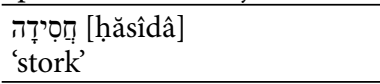 & 11:19, hasida & Deut 14:17, hasida & $\begin{array}{l}\text { 11: } 19, \\
\text { legläg }\end{array}$ \\
\hline $\begin{array}{l}\text { אִ ['ănâfâ] } \\
\text { 'heron; egret' }\end{array}$ & $\begin{array}{l}\text { 11:19, } \\
\text { anafa }\end{array}$ & $\begin{array}{l}\text { Deut 14:18, } \\
\text { anafa }\end{array}$ & $\begin{array}{l}\text { 11:19, } \\
\text { balikčin }\end{array}$ \\
\hline 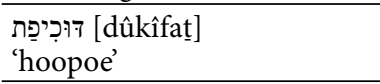 & $\begin{array}{l}\text { 11:19, } \\
\text { duxifat }\end{array}$ & $\begin{array}{l}\text { Deut 14:18, } \\
\text { duxifat }\end{array}$ & $\begin{array}{l}\text { 11:19, } \\
\text { hüd hüdi }\end{array}$ \\
\hline
\end{tabular}

${ }^{51}$ Moreover, a large number of Oghuzic features of Lev 11 of the Göz. 1841 translation (see Işık 2018: 69-75) might go back to the Kieffer 1827. 
Finally, together with the previous paper, 52 different words that stand for different animal species in the Lev of the Göz. 1841 were presented. Among these words, 32 of them show Oghuzic and/or Ottoman Turkish characteristics (62\%), and do not appear in the Lev of the CrKB translation. Moreover, 28 of these Oghuzic words only appear in Chapter 11 (87\%). Thus, Chapter 11 of the Lev in the Göz. 1841 represents an exceptional case when compared to the other chapters, since all the animal names were copied from the same parts of the Kieffer 1827. Due to this, these results once again show that it might be misleading to make far-reaching conclusions regarding the whole edition of the Göz. 1841 based on only one book, since even chapters from the same book present contrasting characteristics. Further analysis of the other Books of the Göz. 1841 might demonstrate whether these characteristics occur systematically in certain chapters or not.

\subsection{An addendum to the previous study}

In my previous study, the Ottoman Turkish Bible data were not compared to the Lev of the Göz. 1841. The direct connection between the Lev 11 translations of the Göz. 1841 and the Kieffer 1827 edition can also be noticed in the previous paper. However, first, I would like to make some corrections regarding the previous data. In Lev 11:29 of the Göz. 1841, I have noted the word göz tök $\ddot{a}$ and claimed that it must be a type of gecko since the Biblical Hebrew form has also been translated as some type of gecko species in other Bible translations and the word tökä might refer 'tokay' gecko. However, in both Ottoman Turkish Bible editions, the word has been translated

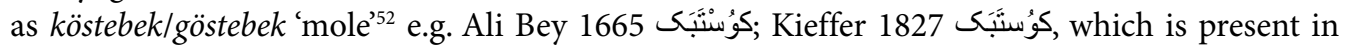
modern Oghuz languages as well, e.g. Tur. köstebek, Az. köstäbäk (KTLS 1: 509-510). Thus, the word should be read as göz töbä ${ }^{53}$. Another possible reading mistake appears in Lev 11:22 of the Göz. 1841 in relation to the word jurjurï/yüryüri 'cricket'. Considering that there exists a word in Turkish, cırcir [jïrjï], which stands for 'cricket', it might seem logical to read the word as jurjuri or jürjüri. However, based on the Kieffer 1827 example, e.g. جُجُج jüdjüd, ${ }^{54}$ and denotes 'cicada. ${ }^{55}$

Finally, below the other animal names for species from Chapter 11 have also been presented and compared to the Ottoman Turkish Bible translations.

\footnotetext{
52 The word has also been denoted as 'mole; mole rat' in at least eight different English Bible translations, e.g. NLT, NASB, NKJV, DBT, etc.

${ }^{53}$ Another reason for this misreading was due to the difficulty of making a distinction between the Hebrew letters ב [bet] and כ כ [kaf] in some parts of the Göz. 1841. Interestingly, the words göz and töbä are also written separately, lacking the final $-k$, e.g. גוז טובר

54 It should be noted that the letters 7 [dalet] and $ר$ [resh] sometimes look identical in the Göz. 1841, which can cause such reading interpretation mistakes. However, it is clear that the word appears in the Hebrew script as ${ }^{55}$ The Ottoman Turkish word was described as orak kuşu in Turkish (Efe 2017: 384), and therefore stands for 'cicada' (ÖTS 4: 3626). It is worth noting that the word jïrjir was also described as 'cicada' in another Ottoman dictionary (Toven 1927: 254) and therefore it is probably a variant of the form judjud.
} 
Table 4. The comparison of the previous data to the Ottoman Bible translations

\begin{tabular}{|c|c|c|c|c|}
\hline Lev & $\begin{array}{l}\text { Other Biblical Animal } \\
\text { Names }\end{array}$ & Göz. 1841 & Kieffer 1827 & Ali Bey 1665 \\
\hline $11: 4$ & ל גָָ [gâmâl] 'camel' & deve 'camel' & deve 'camel' & deve 'camel' \\
\hline $11: 5$ & 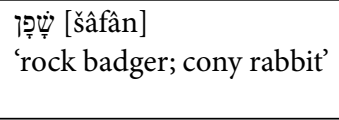 & $\begin{array}{l}\text { ada tavušan } \\
\text { prob. 'hare; European } \\
\text { rabbit' }\end{array}$ & $\begin{array}{l}\text { ada tavšan } \\
\text { 'hare; European } \\
\text { rabbit' }\end{array}$ & $\begin{array}{l}\text { ada tavšan } \\
\text { 'hare; European } \\
\text { rabbit' }\end{array}$ \\
\hline $11: 6$ & 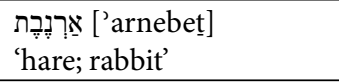 & $\begin{array}{l}\text { tavušan } \\
\text { 'rabbit; hare' }\end{array}$ & $\begin{array}{l}\text { tavšan } \\
\text { 'rabbit; hare' }\end{array}$ & $\begin{array}{l}\text { tavšan } \\
\text { 'rabbit; hare' }\end{array}$ \\
\hline $11: 7$ & $\begin{array}{l}\text { חִ̣ [hăzîr] } \\
\text { 'pig; swine' }\end{array}$ & $\begin{array}{l}\text { Xïnzïr } \\
\text { 'pig; swine' }\end{array}$ & \begin{tabular}{|l} 
hïnzïr \\
'pig; swine'
\end{tabular} & $\begin{array}{l}\text { hïnzïr } \\
\text { 'pig; swine' }\end{array}$ \\
\hline $11: 19$ & $\begin{array}{l}\text { [ִ עִ ['ătallêf] } \\
\text { 'bat' }\end{array}$ & $\begin{array}{l}\text { šepere } \\
\text { prob. 'bat' }\end{array}$ & $\begin{array}{l}\text { šebpere } \\
\text { 'bat' }\end{array}$ & $\begin{array}{l}\text { yarasa } \\
\text { 'bat' }\end{array}$ \\
\hline $11: 22$ & 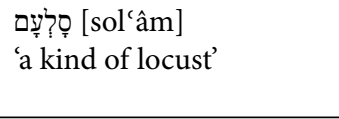 & $\begin{array}{l}\text { yudjud//̌üdjüd } \\
\text { prob. 'cicada' }\end{array}$ & $\begin{array}{l}\text { ǰudjuud/jü̈ď̈üd } \\
\text { 'cicada' }\end{array}$ & $\begin{array}{l}\text { sula'am } \\
\text { (untranslated Biblical } \\
\text { form) }\end{array}$ \\
\hline $11: 22$ & $\begin{array}{l}\text { חִ חִ [hârgôl] } \\
\text { 'a kind of locust' }\end{array}$ & 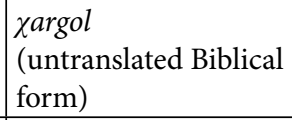 & $\begin{array}{l}\text { hargol } \\
\text { (untranslated Biblical } \\
\text { form) }\end{array}$ & $\begin{array}{l}\text { har'ol } \\
\text { (untranslated Biblical } \\
\text { form) }\end{array}$ \\
\hline $11: 22$ & $\begin{array}{l}\text { חָָּ [hâgâb] } \\
\text { 'locust; grasshopper' }\end{array}$ & 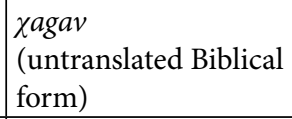 & $\begin{array}{l}\text { hagiab } \\
\text { (untranslated Biblical } \\
\text { form) }\end{array}$ & $\begin{array}{l}\text { hagiab } \\
\text { (untranslated Biblical } \\
\text { form) }\end{array}$ \\
\hline $11: 29$ & $\begin{array}{l}\text { חלֶ̧ôled] } \\
\text { 'mole-rat, mole weasel' }\end{array}$ & $\begin{array}{l}\text { gelinčik } \\
\text { 'mole?' }\end{array}$ & $\begin{array}{l}\text { gelinjik } \\
\text { 'weasel' }\end{array}$ & $\begin{array}{l}\text { gelinjik } \\
\text { 'weasel' }\end{array}$ \\
\hline $11: 29$ & 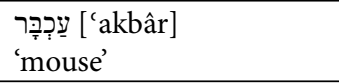 & \begin{tabular}{|l|} 
sičan \\
'rat; mouse'
\end{tabular} & \begin{tabular}{|l|} 
sï̌an \\
'rat; mouse'
\end{tabular} & $\begin{array}{l}\text { sï̌an } \\
\text { 'rat; mouse' }\end{array}$ \\
\hline $11: 29$ & $\begin{array}{l}\text { צ̦ [tsâb] } \\
\text { 'turtle; turtoise; } \\
\text { a kind of lizard' }\end{array}$ & $\begin{array}{l}\text { kapli baga 'turtle; } \\
\text { turtoise' }\end{array}$ & $\begin{array}{l}\text { kaplubuga 'turtle; } \\
\text { turtoise' }\end{array}$ & $\begin{array}{l}\text { kaplubugia } \\
\text { 'turtle; turtoise' }\end{array}$ \\
\hline $11: 30$ & 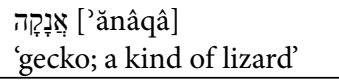 & $\begin{array}{l}\text { sivri sï̌an } \\
\text { prob. 'shrew mouse' }\end{array}$ & $\begin{array}{l}\begin{array}{l}\text { sivri sï̌can 'shrew } \\
\text { mouse' }\end{array} \\
\end{array}$ & $\begin{array}{l}\text { sivri sï̌an } \\
\text { 'shrew mouse' }\end{array}$ \\
\hline $11: 30$ & 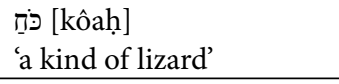 & $\begin{array}{l}\text { güneš kelerisi } \\
\text { lit. 'sun lizard' }\end{array}$ & $\begin{array}{l}\text { güneš keleri } \\
\text { lit.'sun lizard' }\end{array}$ & $\begin{array}{l}\text { güneš keleri } \\
\text { lit.'sun lizard' }\end{array}$ \\
\hline $11: 30$ & $\begin{array}{l}\text { לִ לִ [lețââa] } \\
\text { 'a kind of lizard' }\end{array}$ & $\begin{array}{l}\text { yïldiz kelerisi } \\
\text { lit. star lizard' }\end{array}$ & \begin{tabular}{|l} 
yïldiz keleri \\
lit.'star lizard'
\end{tabular} & $\begin{array}{l}\text { yïldiz keleri } \\
\text { lit.'star lizard' }\end{array}$ \\
\hline $11: 30$ & $\begin{array}{l}\text { טמֶָ [hômeț] } \\
\text { 'lizard' }\end{array}$ & \begin{tabular}{|l} 
kerten kelesi prob. \\
'lizard'
\end{tabular} & \begin{tabular}{|l|} 
kertenkele \\
'lizard'
\end{tabular} & $\begin{array}{l}\text { kertenkele } \\
\text { 'lizard' }\end{array}$ \\
\hline $11: 30$ & 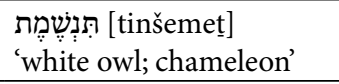 & \begin{tabular}{|l|} 
göz töbä \\
prob. 'mole'
\end{tabular} & $\begin{array}{l}\text { köstebek } \\
\text { 'mole' }\end{array}$ & $\begin{array}{l}\text { köstebek } \\
\text { 'mole' }\end{array}$ \\
\hline
\end{tabular}




\subsection{Copy errors in the Lev of the Göz. 1841}

In both the Göz. 1841 and the Kieffer 1827, the nouns that stand for the unclean animals between Lev 11:4 and Lev 11:29 require an ACC marker due to the Turkic case-marking system of the verbs that have been used in these verses.

Table 5. The commandments regarding unclean animals in Lev 11 of the Kieffer 1827 and the Göz. 1841

\begin{tabular}{|c|c|c|c|}
\hline Lev & $\begin{array}{l}\text { English Standard } \\
\text { Version } 2007\end{array}$ & Kieffer 1827 & Göz. 1841 \\
\hline 11:4 & you shall not eat these & $\begin{array}{l}\text { bunlar }+\ddot{i} \\
\text { these }+ \text { ACC } \\
\text { ye-me- }(y) \text { esiz } \\
\text { to eat-NEG-2PL.JUSS }\end{array}$ & $\begin{array}{l}\text { bular+ } \ddot{i} \\
\text { these+ACC } \\
\text { ye-me- }(y) \text { esiz } \\
\text { to eat-NEG-2PL.JUSS }\end{array}$ \\
\hline $11: 13$ & these you shall detest & $\begin{array}{l}\text { bunlar+ } \ddot{i} \\
\text { these+ACC } \\
\text { mekruh tut-asiz } \\
\text { to regard as abominable-2PL.JUSS }\end{array}$ & $\begin{array}{l}\text { bular+ } \ddot{i} \\
\text { these+ACC } \\
\text { ikrah id-iniz } \\
\text { to disgust-2PL.IMP }\end{array}$ \\
\hline $11: 22$ & of them you may eat & $\begin{array}{l}\text { onlar }+ \text { dan bunlar }+\ddot{i} \\
\text { those }+\mathrm{ABL} \text { these }+\mathrm{ACC} \\
y e-(y) e s i z \\
\text { to eat-2PL.JUSS }\end{array}$ & 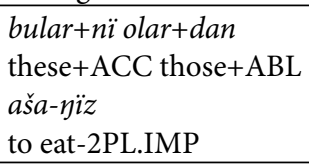 \\
\hline
\end{tabular}

In Crimean Karaim texts, it is natural to see the Oghuzic ACC marker $+(y) I$ (Çulha 2019: 87). However, it should be noted that throughout the Lev of the Göz. 1841, such Oghuzic ACC markers appear only in Chapter 11. Below, the animal names that contain Oghuzic ACC markers in the Book are shown.

Table 6. The Oghuzic accusative case markers in the Lev of the Göz. 1841

\begin{tabular}{|c|c|c|}
\hline The Lev & Kieffer 1827 & Göz. 1841 \\
\hline $11: 6$ & $\begin{array}{l}\text { tavšan }+\ddot{i} \\
\text { rabbit; hare+ACC }\end{array}$ & $\begin{array}{l}\text { tavušan+ } \ddot{i} \\
\text { rabbit; hare+ACC }\end{array}$ \\
\hline $11: 7$ & $\begin{array}{l}\text { hïnzïr+ } \ddot{i} \\
\text { pig; swine+ACC }\end{array}$ & 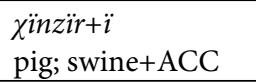 \\
\hline $11: 14$ & $\begin{array}{l}k u z \dot{g} u n+\ddot{i} \\
\text { raven }+\mathrm{ACC}\end{array}$ & $\begin{array}{l}k u z \dot{g} u n+\ddot{i} \\
\text { raven }+\mathrm{ACC}\end{array}$ \\
\hline $11: 16$ & $\begin{array}{l}\text { dogian+ } \ddot{i} \\
\text { hawk; falcon+ACC }\end{array}$ & $\begin{array}{l}d u \dot{g} a n+\ddot{i} \\
\text { hawk; falcon+ACC }\end{array}$ \\
\hline $11: 19$ & $\begin{array}{l}\text { balikečïn+ } \ddot{i} \\
\text { heron; egret+ACC }\end{array}$ & $\begin{array}{l}\text { balikčïn+ } \ddot{i} \\
\text { heron; egret+ACC }\end{array}$ \\
\hline
\end{tabular}

Although the above instances cannot be regarded as copy errors, it is possible to claim that the Kieffer 1827 has influenced the Göz. 1841 regarding such usages as well. The other examples below clearly illustrate some interesting copy mistakes, since the lexical items in the Kieffer 1827 were copied into the Göz. 1841 together with their Oghuzic ACC markers, and later the Kipchak ACC markers were also attached to these forms. 
Table 7. The double accusative case markers in the Lev of the Göz. 1841

\begin{tabular}{|c|c|c|}
\hline Lev & Kieffer 1827 & Göz. 1841 \\
\hline $11: 13$ & $\begin{array}{l}\text { iron+ } \ddot{i} \\
\text { eagle+ ACC (ogh.) }\end{array}$ & $\begin{array}{l}\text { iron+ }+\ddot{i}+n \ddot{i} \\
\text { eagle+ACC (ogh.)+ACC (kip.) }\end{array}$ \\
\hline $11: 16$ & $\begin{array}{l}\text { baykuš+ } \ddot{i} \\
\text { owl+ACC (ogh.) }\end{array}$ & $\begin{array}{l}\text { baya kuš+ } \ddot{i}+n \ddot{i} \\
\text { owl+ACC (ogh.)+ACC (kip.) }\end{array}$ \\
\hline $11: 17$ & $\begin{array}{l}t u+y \ddot{i} \\
\text { owl+ACC (ogh.) }\end{array}$ & $\begin{array}{l}\text { to }+y \ddot{i}+n \ddot{\imath} \\
\text { owl?+ACC (ogh.)+ACC (kip.) }\end{array}$ \\
\hline 11:18 & $\begin{array}{l}\text { rah }(a) m+\ddot{i} \\
\text { carrion vulture+ACC (ogh.) }\end{array}$ & $\begin{array}{l}\text { raham }+\ddot{i}+n \ddot{i} \\
\text { carrion vulture+ACC (ogh.)+ ACC (kip.) }\end{array}$ \\
\hline $11: 19$ & $\begin{array}{l}\text { hüdhüd+i } \\
\text { hoopoe+ACC (ogh.) }\end{array}$ & $\begin{array}{l}\text { hüdhüd+i+ni } \\
\text { hoopoe+ACC (ogh.)+ACC (Kip.) }\end{array}$ \\
\hline $11: 20$ & $\begin{array}{l}\text { jü djüd }+i \\
\text { cicada }+ \text { ACC (ogh.) }\end{array}$ & 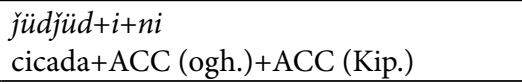 \\
\hline
\end{tabular}

In Lev 11:29, the Kieffer 1827 and the Göz. 1841 show different translation strategies. Based on the structures, animal names require an ACC marker in the Kieffer 1827, unlike the Göz. 1841.

Table 8. The different translation strategies in the Lev of the Kieffer 1827 and the Göz. 1841

\begin{tabular}{ll|ll}
\hline Lev & English Standard Version & Kieffer 1827 & Göz. 1841 \\
\hline $11: 29$ & these are unclean to you & bunlar+ $\ddot{i}$ & bu+dur siz+e \\
& & these + ACC & this+COP you (2PL)+DAT \\
& & napak tut-asïz & o haram \\
& & to regard as unclean-2PL.JUSS & the $^{56}$ illicit \\
\hline
\end{tabular}

In the aforementioned verse, a different copy error is also present in three words. In Turkic languages, the structure of compound nouns usually appears as 'noun+noun+3SG.POSS' or 'noun+noun'. However, it seems that the words güneš kelerisi and yïldiz kelerisi were copied from the Kieffer 1827 into the Göz. 1841 together with their 3SG.POSS suffixes and another 3SG.POSS marker was also attached to these forms. Besides this, a 3SG.POSS marker was also attached to the Turkish word kertenkele in an unusual way, as the form is already a compound noun.

Table 9. The unusual usage of 3SG.POSS suffixes in the Lev of the Göz. 1841

\begin{tabular}{|c|c|c|}
\hline Lev & Kieffer 1827 & Göz. 1841 \\
\hline $11: 29$ & $\begin{array}{l}\text { güneš keler+i+ni } \\
\text { sun lizard+3SG.POSS+ACC }\end{array}$ & $\begin{array}{l}\text { güneš keler }+i+s i \\
\text { sun lizard }+3 \text { SG.POSS }+3 \text { SG.POSS }\end{array}$ \\
\hline $11: 29$ & $\begin{array}{l}\text { yïldiz keler+i+ni } \\
\text { star lizard+3SG.POSS+ACC }\end{array}$ & $\begin{array}{l}\text { yildiz keler }+i+s i \\
\text { star lizard+3SG.POSS }+3 \text { SG.POSS }\end{array}$ \\
\hline $11: 29$ & $\begin{array}{l}\text { kertenkele }+y i \\
\text { lizard }+ \text { ACC }\end{array}$ & $\begin{array}{l}\text { kerten kele }+s i \\
\text { lizard+3SG.POSS }\end{array}$ \\
\hline
\end{tabular}

${ }^{56}$ It is vastly known that the Turkic languages do not have definite article. However, one of the most common features of the Karaim Bible translations is rendering the Hebrew definite article ה־ [ha-] by some Turkic demonstrative pronouns, e.g. $o l, o$, šol etc. 
Finally, the results of the present study show that five words that were listed in the Karaim dictionaries for Crimean Karaim might be incorrect according to their descriptions. Note that all these problematic words originally belong to Shapsal's lexical material ${ }^{57}$, and therefore to the KRPS dictionary. In the dictionary, the Karaim words have been listed together with Russian and Polish descriptions. The following is a comparison of the Russian descriptions of these problematic words to the relevant parts of a Russian Bible translation from the $19^{\text {th }}$ century (RSO 1876) in order to present a possible explanation for these disputed descriptions.

First of all, as was demonstrated, the word toyï (Lev 11:17, Göz. 1841) can be traced back to the word ' $t u+y i$ ', which appears in the Kieffer 1827 and stands for 'a kind of owl+ACC', whereas it was defined as 'ibis' (Rus. $u \sigma u c$ ) in the Karaim dictionaries (CKED: 410, KRPS: 535). The same Russian equivalent is also present in RSO 1876, e.g. Lev 11:17, uбuc 'ibis'. The second word kuku kuši (Lev 11:16, Göz. 1841) denotes 'seagull; mew' (Rus. чайка) (CKED: 319, KRPS: 374) in the Karaim dictionaries, whereas it stands for 'cuckoo' in the Kieffer 1827. Similar to the previous example, the meaning in the KRPS matches with the Russian Bible translation, e.g. Lev 11:16, RSO 1876; чайки 'seagulls'. The next word karabatak has been listed as 'fisher (bird); tern' (Rus. рыболова lit. 'fisher (bird)', Pol. rybitwa 'tern') in the Karaim dictionaries (CKED 290, KRPS: 363,) whereas it represents 'cormorant' in Oghuzic languages and the Kieffer 1827. The Russian Bible translation presents the identical form in Lev 11:17 as well, e.g. RSO 1876, рыболова lit. 'fisher'. Another word has been listed as ak-baba kuši 'kite; hawk' in the KRPS: $377^{58}$ (Rus. кориун 'kite', Pol. jastrząb 'hawk'), whereas it denotes 'vulture' in Turkish and the Kieffer 1827. Once again, the Russian description in the KRPS has been attested in the RSO 1876 as well, e.g. Lev 11:17 кориун 'kite' Hereby, I consider that the words toyï, kuku, karabatak, and ak baba kušï have most probably been collected from the Lev of the Göz. 1841 (or other texts that also have used the Göz. 1841 as their source) and the meanings of these erroneous/unclear forms might have been compared to their controversial equivalents in some other Bible translations. For instance, the Russian descriptions of the aforementioned words in the KRPS also appear in the Russian Bible translation from the $19^{\text {th }}$ century mentioned above. Nevertheless, it is not clear whether Shapsal himself had analyzed the Lev of the Göz. 1841 and compared these problematic forms with other Bible translations. This is especially true considering that there are at least eight bird names that appeared in the same part of the Göz. 1841, but were not listed in the KRPS, e.g. gügürčin/gögürčün, ïronï, deyiz kartalï, čaylak, deve kušu, ügi kušu, balikčìn, hüd hüdi.

The final debated word is gelinčik, which was presented in the previous study (Işı1k 2020: 152). As was mentioned, the word gelinjik appears in the Oghuz branch and Crimean Tatar with the meaning of 'weasel', e.g. Tur. gelincik (ÖTS 2: 1675), Az. gälincik (ADIL II: 230), CrTat. келинчек [kelinček] (KRUS: 223) whereas there exist some common forms that stand for 'weasel' among the Kipchak languages, e.g. Kaz. küzen, Kir. küzön, Tat. közän, CrTat. küzen (DTMK: 119, EDPT: 761, L:163). However, according to KRPS: 166 and CKED: 164, the word gelinčik denotes 'mole'59 in Crimean Karaim. Considering the strong link between the Lev translations of the Kieffer 1827 and the Göz. 1841 for animal names, the interpretation of the word as 'mole' might be incorrect. In

57 Shapsal's data are generally considered to be reliable when compared with some other materials. Nevertheless, some problematic cases have briefly been mentioned in the CKED: 9-10 as well.

58 This word was not listed in the CKED.

59 Interestingly, the Biblical Hebrew word חלד [hôled] (Lev 11:29) has been translated in some English Bible translations (at least eight) as 'mole; mole rat', e.g. ESV, NKJV, NAS 1977, etc., whereas in most of the English Bible translations (at least 16) the word was denoted by 'weasel', e.g. NIV, KJB, ASV, etc. 
fact, the Russian word кpom 'mole' in the KRPS dictionary is present in the RSO 1876 as well, e.g. Lev 11:29, кpom. Besides this, the corrected reading of the word göz töbä (see 3.2.) clearly shows that there is another word that also stands for 'mole' only a verse later. However, it should be noted that the word kelincek/kelincik has also been listed as meaning 'mole' in Halitch Karaim ${ }^{60}$ (ESTJa 3: 18, KRPS: $302^{61}$ ). Stachowski (KEWTS: 155) claims that the two animals have some common features which might cause such semantic developments. Ergo, it is difficult to determine the meaning of the word gelinčik in Crimean Karaim, whereas in the Göz. 1841 it clearly denotes 'weasel'. Perhaps some analysis of the Karaim texts might shed light on the issue of this word. Furthermore, possible attestations of the aforementioned erroneous forms in Karaim texts might also be significant in explaining the link between such sources.

\section{ACKNOWLEDGEMENT}

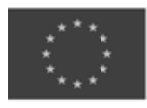

The research upon which this publication is based has been awarded funding from the European Research Council (ERC) under the European Union's Horizon 2020 research and innovation programme (grant agreement no. 802645).

\section{ABBREVIATIONS}

Bible Translations: AKJV = American King James Version; ASV = American Standard Version; BSB = Berean Study Bible; BST = Brenton Septuagint Translation; $\mathrm{CrKB}=$ Critical edition of a Crimean Karaim Bible Edition (2019); CSB = Christian Standard Bible; DBT = Darby Bible Translation; DRB = Douay-Rheims Bible; ERV = English Revised Version; ESV = English Standard Version; Göz. 1841 = Gözleve Bible (1841); GWT = GOD'S WORD $^{\oplus}$ Translation; ISV = International Standard Version; JB2000 = Jubilee Bible 2000; KJB = King James Bible; NAS 1977 = New American Standard 1977; NASB = New Americ ; NETB = NET Bible; NHEB = New Heart English Bible; NIV = New International Version; NKJV = New King James Version; NLT = New Living Translation; RSO (1876) = Russian Synodal Orthodox Version 1876; WBT = Webster's Bible Translation; YLT = Young's Literal Translation

Biblical Books: Deut = Deuteronomy; Exo = Exodus; Gen = Genesis $;$ Lev = Leviticus; Num = Number;

Languages: Az. = Azerbaijani; CrTat. = Crimean Tatar; Gag. = Gagauz; HKar. = Halitch Karaim; Kaz. = Kazakh; Khak. = Khakas; Kir. = Kirghiz; Nog. = Nogai; Ot. = Ottoman Turkish; Pol. = Polish; Rus. = Russian; Tat. $=$ Tatar; Trk. $=$ Turkmen; Tur. $=$ Turkish; Uyg. $=$ Uyghur; Uzb. $=$ Uzbek; Yak. = Yakut $($ Sakha $)$;

Other Abbreviations: $2 \mathrm{PL}=$ second person plural; $3 \mathrm{SG}=$ third person singular; $\mathrm{ABL}=$ ablative; $\mathrm{ACC}=$ accusative; Cop = copula; GEN = genitive; IMP = imperative; JUSS = jussive; kip. = Kipchak; lit. = literally; $\mathrm{NEG}=$ negation; ogh. $=$ Oghuzic; PART $=$ participle POSS = posssessive marker; prob. $=$ probably

60 On the other hand, in Trakai Karain, 'mole' was denoted by the Russian word krot (KRPS: 341 ).

61 This lexical item was originally listed in Markowkicz 1933: 42. 


\section{Manuscripts and Fragments of the Lev of the CrKB}

Baxč. $116=$ This is preserved in the Russian National Library, and was copied in the 18th century. It contains fragments of the Pentateuch (Exodus 26-40, Leviticus, Numbers, Deuteronomy), three books of the Five Scrolls (Song of Songs, Ruth, Lamentations), and some parts of Psalms (1-19, 22-37, 55-57, 69-89). Only a few available leaves were employed in the Lev of the CrKB: Lev 3:10-4:7, 5:23-6:7, 8:36-10:4, 15:30-16:8. BSMS $288=$ This is in the Cambridge University Li180brary (among the holdings of the British and Foreign Bible Society) in four volumes; volume I - 203 text leaves (Pentateuch and Five Scrolls), volume II - 144 text leaves (Former Prophets), volume III - 155 text leaves (Latter Prophets), and volume IV -118 text leaves (Writings). The manuscript contains the whole Tanakh without the Chronicles. In the $\mathrm{CrKB}$, only the volumes I and IV have been included as the basic manuscript.

Evr I $143=$ The available fragments consist of Lev 1:1-15 and Lev 16:4-5.

\section{REFERENCES}

Adamović, Milan 2001. Das Türkische des 16. Jahrhunderts nach den Aufzeichnungen des Florentiners Filippo Argenti. Göttingen: Pontus Verlag.

ADIL = Orucovun, Oliheydər 2006. Azerbaycan Dilinin İzanlı Lüğäti. Vol. I-IV. [The annonated dictionary of the Azerbaijani language] Bakı: Şərq Qərb.

Cansdale, George Soper 1970. Animals of Bible Lands. Exeter: Paternoster.

CC = GRøNBECH, Kaare 1942. Romanisches Wörterbuch, Türkischer Wortindex zu Codex Cumanicus. [Monumenta Linguarum Asiae Maioris Subsidia 1.] Kopenhagen: Munksgaard.

CEDHL $=$ KLEIN, Ernest 1987. A Comprehensive Etymological Dictionary of the Hebrew Language for Readers of English. Israel: Carta Jerusalem.

CKED = AQTAY Gülayhan and Henryk JANKowski 2015. A Crimean Karaim-English Dictionary. Poznań: Uniwersytet im. Adama Mickiewicza w Poznaniu. Katedra Studiów Azjatyckich. Wydział Neofilologii.

CPED $=$ SteIngass, Francis 1963. A Comprehensive Persian-English Dictionary. London: Routledge \& Kegan Paul Limited.

CrKB = Jankowski, Henryk, Gülayhan Aqtay, Dorota CegioŁka, Tülay Çulha and Michał Németh 2019. The Crimean Karaim Bible Vol. I-II. Wiesbaden: Harrossowitz Verlag.

ÇulHA, Tülay 2019. Karaycanın Karşılatırmalı Grameri [Comparative Grammar of Karaim]. Ankara: Türk Dil Kurumu.

DİLçİN, Cem 1991. Mes' ûd Bin Ahmed 'Süheyl ü Nev-bâhar' Inceleme-Metin-Sözlük [Mes' ûd Bin Ahmed 'Süheyl ü Nev bahar' Analysis-Text-Dictionary]. Ankara: Atatürk Kültür Merkezi Yayınları.

DLT = AtAlay, Besim 1985. Divanü Lugat-it-Türk Tercümesi [The translation of Dīwān Lughāt al-Turk]. Vol. I-IV. Ankara: Türk Dil Kurumu Yayınları.

Doerfer, Gerhard 1959. 'Das Krimosmanische.' In: Jean Dely et al. (eds.) Philologiae Turcicae Fundamental. Wiesbaden: F. Steiner, 272-280.

DTMK = HAUENSCHILD, Ingeborg 2003. Die Tierbezeichungen bei Mahmud al-Kaschgari; Eine Untersuchung aus sprach-und kulturhistorischer Sicht. [Turcologica 53] Wiesbaden: Harrassowitz Verlag.

EDPT $=$ Clauson, Sir Gerard 1972. An Etymological Dictionary of Pre-Thirteenth Century Turkish. Oxford: The Clarendon Press.

Efe, Kürşat 2017. 'Tarihî Türk Lehçelerinde Alıntı Hayvan İsimleri [Loan Animal Names in the Historical Turkic Languages].' Route Educational and Social Science Journal 4(5): 379-393. 
ESTJa 1-3 = Sevortjan, Ervand Vladimirovič [Севортян, Эрванд Владимирович] 1974, 1978, 1980. Этимологический Словарь Тюркских Языков: Общетюркские И Межтюркские Основы На Буквы А, Б, $B$, , Д. Москва: Восточная литература РАН.

ESTJa 5 = Levitskaja L. S. [Левитская Л. C.], A. V. Dyво [А. В. Дыбо], V. I. Rassadin [В. И. Рассадин] 1997. Этимологический Словарь Тюркских Языков: Общетюркские И Межтюркские Основы На Буквы ' $К$ ', ' Қ’. Москва: Восточная литература РАН.

ESTJa 6 = Levitskaja L. S. [Левитская Л. С.], А. V. Dyво [А. В. Дыбо], V. I. Rassadin [В. И. Рассадин] 2000. Этимологический Словарь Тюркских Языков: Общетюркские и Межтюркские Основы на Буквы 'Қ'. Москва: Восточная литература РАН.

Ferguson, Walter 1974. Living Animals of the Bible. New York: Scribner.

Griščenko, Aleksandr I. [Александр И. Грищенко] 2017а. “Дикие звери» Сигизмунда Герберштейна и перечень чистых копытных в правленом славяно-русском пятикнижии.' Slavistična revija letnik 65/2017, št. 4.

GriščEnKo, Aleksandr I. [Александр И. Грищенко] 2017b. 'Правленое славяно-русское Пятикнижие XV века и тюркский таргум: проблема взаимного влияния.' Rossica Olomucensia LVI: 5-51.

IrqB = Tekin, Talat 1993. Irk Bitig: The Book of Omens. [Turcologica 18.] Wiesbaden: Harrassowitz Verlag.

IşıK, Murat 2018. 'Oghuzic and Kipchak Characteristics in the Book of Leviticus, Gözleve Bible (1841).' Rocznik Orientalistyczny LXXI/2: 66-76.

IşıK, Murat 2020. 'The Animal Names in the Book of Leviticus of the Gözleve Bible (1841). Part I: Mammal, Insect and Reptile Species.' In: István Zımonyı (ed.) Ottomans - Crimea - Jochids. Studies in Honour of Mária Ivanics. Szeged: University of Szeged, Department of Altaic Studies, 145-163.

Jankowski, Henryk 1997. 'A Bible Translation into The Northern Crimean Dialect of Karaim.' Studia Orientalia 82: 1-84.

Jankowski, Henryk 2015. 'Crimean Turkish Karaim and the Old Northwestern Turkic Tradition of The Karaites.' AOH 68/2: 199-214.

Jankowski, Henryk 2018. 'Translation of the Tanakh into Crimean Karaim: History, Manuscripts, and Language.' In: Lily KaHN (ed.) Jewish Languages in Historical Perspective. [IJS Studies in Judaica, Vol. 17.] Leiden: Brill, 39-61.

Karahan, Akartürk 2013. 'Codex Cumanicus'ta Hayvan Adları [The animal names in Codex Cumanicus].' Turkish Studies 8/1: 1839-1865.

KEWTS = STACHOWsкI, Marek 2019. Kurzgefaßtes etymologisches Wörterbuch der türkischen Sprache. Kraków: Księgarnia Akademicka.

KB = ARAT, Reşit Rahmeti 1947. Kutadgu Bilig I Metin [Kutadgu Bilig I text]. İstanbul: Milli Eğitim Basımevi. KI = CAFEROĞLU, Ahmet 1931. Abû Hayyân Kitâb al-İdrâk li-Lisân al-Atrâk [Abû Hayyân's'The comprehension book of the Turkic languages']. İstanbul: Evkaf Matbaasi.

Kizılov, Mikhail 2009. The Karaites of Galicia: An Ethnoreligious Minority Among the Ashkenazim, the Turks, and the Slavs, 1772-1945. Leiden: Brill.

KRPS = BASKAKOv N. А. [Баскаков Н. А.], А. ZајА̨СZкоWSкі [А. Зайончковский], S. М. SнAPSHAL [C. M. Шапшал] 1974. Караимско-Русско-Польский Словарь. Москва: Русский Язык.

KRUS = UseINov, S. М. [Усеинов, С. М.] 2008. Крымскотатарско-Русско-Украинский Словарь. Акъмесджит: Тезис нешрият эви.

KTS = Koç Kenan and Vehbi BAşKAPAN 2003. Kazak Türkçesi Türkiye Türkçesi Sözlüğü. [Kazakh Turkish Turkey Turkish Dictionary.] Ankara: Akçağ Yayınları.

KTLS = ERCİLAsun, Ahmet Bican 1991. Karşılaştırmalı Türk Lehçeleri Sözlüğ̈̈ [Comparative Dictionary of Turkic Languages] Vol. I-II. Ankara: Kültür Bakanlığı Yayınları. 
KW = KaKuK, Zsuzsa 2012. Krimtatarisches Wörterverzeichnis. Szeged: SZTE Altajisztikai Tanszék.

L = Tenıšev E. R. [Тенишев Э. P.], N. Z. GadZhieva [Н. 3. Гаджиева], В. А. Serebrennikov, [Б. А. Сepeбренников] 1997. Сравнительно-историческая грамматика тюркских языков: Лексика. Москва: Наука.

LVTL $=$ KoeHLER Ludwig and Walter BAUMgarTner 1985. Lexicon in Veteris Testamenti Libros Vol. 1-2. Leiden: E. J. Brill.

Mardkow1Cz, Aleksander 1933. Stownictwo Karaimskie. Karaimsko-Polsko-Niemiecki Stownik. Westkaraimische Sprache. Karaimisch-Polnisch-Deutsches Wörterbuch. Łuck.

NÉmETH, Michał 2015. 'An early North-Western Karaim Bible translation from 1720. Part 3: A contribution to the question of the stemma codicum of the Eupatorian print from 1841.' Karaite Archives 3: 103-118.

NÉmETH, Michał 2016. 'A Crimean Karaim Handwritten Translation of the Book of Ruth dating from 1687.' Türk Dilleri Araştırmaları 26. 2: 161-226.

NS = NİşANYAN, Sevan 2018. Nişanyan Sözlüğ̈̈. [Nişanyan Dictionary]. İstanbul: Liber Plus Yayınları.

Olach, Zsuzsanna 2016. 'A karaim nyelvü Gözlevei Biblia nyelvészeti tanulságai.' Keletkutatás 2016/ősz: 29-52.

OTAL = DevellíoĞLu, Ferit 2010. Osmanlıca - Türkçe Ansiklopedik Lûgat. [Ottoman - Turkish Encyclopedic Dictionary.] Ankara: Aydın Kitabevi.

OTWP = ERdAL, Marcel 1991. Old Turkic Word Formation. Vol. I. [Turcologica 7.] Wiesbaden: Harrassowitz Verlag.

ÖTS = ÇAĞBAYıR, Yaşar 2007. Ötüken Türkçe Sözlük. [Ötüken Turkish Dictionary].Vol 1-5. İstanbul: Ötüken Neşriyat.

Pawlina, Agata 2016. 'The Pole Who Translated the Bible for the Turks.' The Polish Journal of Biblical Research 15/2:31-37.

Privratsky, Bruce G. 2014. 'A History of Turkish Bible Translations.' [Online access:] https://historyofturkishbible.wordpress.com; 05/10/2020]

RTD = REDHOUsE, James William 1884. Redhouse's Turkish Dictionary in two parts: English \& Turkish, Turkish \& English. London: Quaritch.

SchöNig, Claus 2010. 'Osmanische Einflüsse auf das Krim-Areal'. In: Elżbieta Mańczak-Wohlfeld and Barbara Podolak (eds.) Studies on the Turkic world. A Festschrift for Professor Stanisław Stachowski on the Occasion of His 80th Birthday. Kraków: Jagiellonian University Press, 107-119.

Shapira, Dan 2003. 'The Turkic Languages and Literatures of the East European Karaites.' In: Meira PoLLIACK (ed.) Karaite Judaism. A Guide to its History and Literary Sources. Leiden-Boston: Brill, 657-707.

SHAPIRA, Dan 2005. 'Jewish Pan-Turkist: Seraya Szapszał (Şapşaloğlu)And His Work Qırım Qaray Türkleri (1928)... AOH 58/4: 349-380.

ShapIRA, Dan 2013. 'The Karaim translation of the Book Of Nehemia copied in the 17th century's Crimea and printed in 1840/1841 at Gözleve, on the copyist of the manuscript, and some related issues.' Karaim Archives 1: 133-198.

TDTLM = Mirzəliyeva, Məhəbbət (eds.) 2004. Türk Dillarinin Tarixi-Müqayisəli Leksikologiyasi Məsəlalari. [The Issues of the Historical-Comparative Lexicology of the Turkic Languages]. Vol. I. Bakı: Bakı Slavyan Universiteti Kitab Aləmi Nəşriyyat-Poliqrafiya Mərkəzi.

TLO = Menınsk1, Franciscus à Mesgnien 1680. Thesaurus Linguarum Orientalium Turcicae-Arabicae- Persicae: Lexicon. Vol. I-IV. Viennæ: Franciscus à Mesgnien Meninski.

TMEN = DoERfER, Gerard. 1963-1975. Türkische und Mongolische Elemente im Neupersischen. Vol 1-4. Wiesbaden: Franz Steiner Verlag. 
Toven, Mehmed Bahaeddin 1927. Yeni Türkçe Lügat. [New Turkish Dictionary]. İstanbul: Evkaf-I İslamiye Matbaasi.

TS = Aksoy Ömer Asım and Ali Dehri DİLçİ̀ 2009. Tarama Sözlü̆̆̈̈ [Compiled Dictonary]. Vol I-VIII. Ankara: Türk Dil Kurumu Yayınları.

TTL = Johanson Lars and Éva Ágnes Csató (eds.) 1998. The Turkic Languages. New York and London: Routledge.

Turan, Nihat 1990. Kuşlar: Türkiye’nin Av ve Yaban Hayvanları. [Birds: The Game and Wild Animals of Turkey]. Vol. 2. Ankara: O.G.M, Eğitim Dairesi Başkanlığı, Yayın ve Tanıtma Şube Müdürlüğü.

WAED = Wortabet, William Thomson, Harvey Porter, and John Wortabet 1984. Wortabet's Arabic-English Dictionary. Beirut: Librairie du Liban.

WOT = RónA-TAS András and Árpád Berta 2011. West Old Turkic. Turkic Loanwords in Hungarian. Vol I-II. [Turcologica 84.] Wiesbaden: Harrassowitz Verlag.

Zenker, Julius Theodor 1866, 1876. Türkisch-Arabisch-Persisches Handwörterbuch: Dictionnaire Turc-ArabePersan. Vol I-II. Leipzig: Engelmann.

Open Access. This is an open-access article distributed under the terms of the Creative Commons Attribution 4.0 International License (https://creativecommons.org/licenses/by/4.0), which permits unrestricted use, distribution, and reproduction in any medium, provided the original author and source are credited, a link to the CC License is provided, and changes - if any - are indicated. (SID_1) 